\title{
1 Technical Challenges in Operating an SOFC in Fuel Flexible Gas 2 Turbine Hybrid Systems: Coupling Effects of Cathode Air Mass 3 Flow
}

4 Nor Farida Harun ${ }^{\mathrm{a}}$, David Tucker ${ }^{\mathrm{a}}$, Thomas A. Adams II ${ }^{\mathrm{b}}$

${ }^{a}$ U.S. Department of Energy, National Energy Technology Laboratory, 3610 Collins Ferry Road, Morgantown, West Virginia 26507-0880, United States

${ }^{b}$ Department of Chemical Engineering, McMaster University, 1280 Main Street West, Hamilton, Ontario L8S 4L7, Canada

\section{Abstract}

Considering the limited turndown potential of gasification technologies, supplementing a fuel cell turbine hybrid power system with natural gas provides flexibility that could improve economic viability. The dynamic characterization of fuel composition transients is an essential first step in completing the system identification required for controls development. In this work, both open loop and closed loop transient responses of the fuel cell in a solid oxide fuel cell (SOFC) gas turbine (GT) hybrid system to fuel composition changes were experimentally investigated using a cyber-physical fuel cell system. A transition from methane lean syngas to methane rich gases with no turbine speed control was studied. The distributed performance of the fuel cell was analyzed in detail with temporal and spatial resolution across the cell.

Dramatic changes in fuel cell system post combustor thermal output or "thermal effluent" resulting from anode composition changes drove turbine transients that caused significant cathode airflow fluctuations, by as much as $8 \%$ in less than a minute. In comparing the open loop responses to identical tests conducted under closed loop conditions without significant airflow changes, it was discovered that the cathode airflow change was a major linking event in short-term system transient response. The results suggested that modulating cathode air flow in response to fuel composition changes offers promise for the dynamic control of SOFC/GT hybrid systems with fuel flexibility.

Keywords: Open loop characterization; fuel composition changes; cathode air mass flow; fuel cell gas turbine hybrid; cyber-physical simulations.

\section{Introduction}

High temperature solid oxide fuel cells (SOFC) are most beneficial for power generation hybridization with thermal-based generator systems as compared to other fuel cell technologies because of their high operating temperatures. For example, SOFCs can be integrated with a bottoming gas turbine cycle to exploit the benefits of high quality waste heat and fuel recovery from the fuel cell stacks for additional power production $[1,2]$. Direct-fired solid oxide fuel cell gas turbine (SOFC/GT) hybrid systems shown in Figure 1 also offer some advantages in terms of air pressurization as a result of turbomachinery pressure ratio effect on fuel cell Nernst potentials, and heat recovery of gas turbine exhaust [3]. Both high pressure and heat recuperation directly help the total system efficiency [3].

SOFC/GT systems are also considered economically feasible for early technology adoption because the fuel cell lifetime could be extended in a hybrid configuration [4]. The voltage degradation rate of SOFCs can be minimized as there are potentials to operate the SOFCs at lower fuel utilization, while maintaining high total system efficiency, as opposed to standalone gas turbines or SOFCs. Although a commercial direct-fired SOFC/GT plant does not exist yet, the U.S. Department of Energy (DOE), National Energy Technology Laboratory (NETL) has built a world-leading cyber-physical system that mimics an SOFC system in a hybrid configuration using the seamless integration of a numeric model with hardware, and then coupled the hardware to a real recuperated gas turbine cycle [5]. The hardware test facility at NETL is able to emulate SOFC/GT hybrid dynamics performance, aimed at improving the system flexibility and achieving DOE efficiency targets.

The potential of fuel flexibility in high temperature SOFCs makes this technology more feasible to handle fuel composition fluctuations or drastic changes in fuel type. At an operating temperature higher than $600^{\circ} \mathrm{C}$, SOFCs have high potential to run on various conventional fuels (e.g. natural gas, coal-derived syngas, and reformed diesel) and alternative fuels (e.g. biogas, ethanol, and biodiesel). An optimization study in advanced power generation systems that considered both economics and environmental impacts has suggested that flexible operations are important for meeting new economic situations that experience changes in fuel prices or new energy policies, and current as well as expected environmental regulations [5]. The study showed that the net present value (NPV) of a polygeneration plant for power and chemical production could improve up to

Corresponding author. Tel.:+1 304285 0581; E-mail address: nor.harun@netl.doe.gov; adfarimie@yahoo.com (Nor Farida Harun) 
$63 \%$ if the system is $100 \%$ flexible [6]. In this example, dynamic shifting in fuels can be one possible strategy to manage fuel cell and gas turbine power for load following or chemical production balance during peak seasons and off-peak seasons to maximize the plant profits.

However, some practical issues may prevent changes to fuel composition input to the existing SOFC technologies because different fuels result in different temperature performance, fuel utilization, and electrochemical properties, all of which play an important role in the lifetime of a fuel cell [7, 8]. Thermal management was identified to be one of the greatest challenges to operate SOFC systems using different fuel compositions or fuel types [7,9]. For instance, the use of methane in SOFCs could cause problematic temperature gradients across the cell due to the endothermic cooling effect of internal methane reforming. Disproportionate cooling and heating may also occur locally along the cell as a result of internal methane reforming, water-gas shifting, and electrochemical reactions. Thus, fuel cell performance degradation will be a major hurdle since the degradation rate may be accelerated if the system operates at lower solid temperature, including average and localized temperature, high current density, and high fuel utilization [10]. Lowering the fuel cell stack temperature in SOFC/GT hybrids will decrease the turbine speed and turbine efficiency, which eventually affect the upstream conditions of SOFC stack. The relationship between the solid temperature and the turbine performance was studied in different transient conditions, such as, during diurnal changes in ambient conditions [11] and part load operations [12,13].

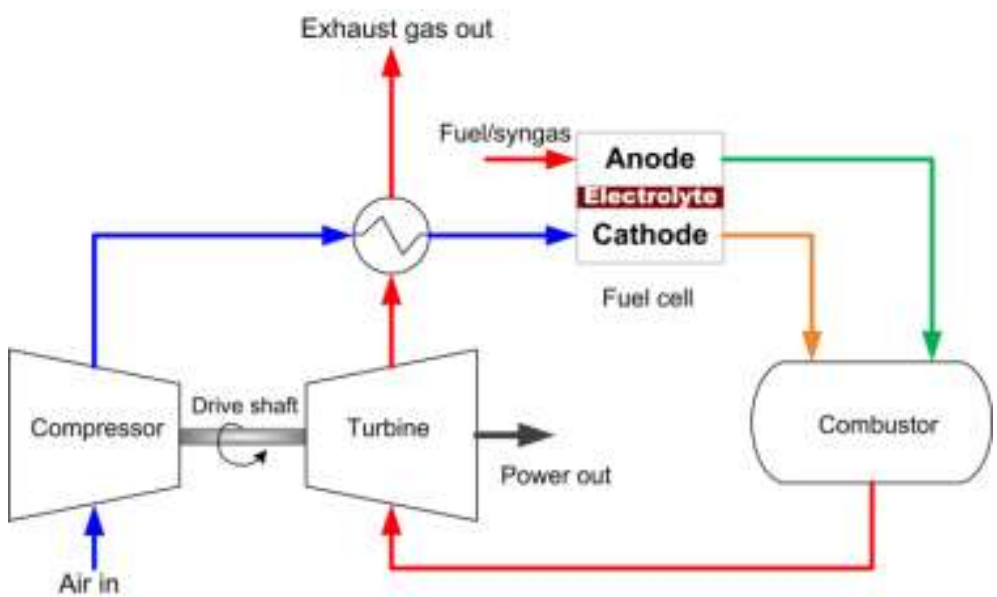

Figure 1: Basic flow diagram of a SOFC/GT hybrid system

Considering the strong coupling between fuel cell systems and the balance of the SOFC/GT plant, problems with system performance as a result of fuel flexible operations could be arise. Severe fuel cell damage due to thermal stress, unbalanced pressure between anode and cathode, shaft over speed, compressor surge and stall may result if the transient is too fast [14-16]. In fact, controls for thermal management and degradation for flexible fuel operations are not available yet. In addition, the range of fuel flexibility that could be implemented in SOFC systems is still under research [17]. Although the aforementioned challenges during fuel dynamic operations could be expected based on simulation results or available observations in standalone fuel cell systems, the consequences in the hybrid cycles have not yet been investigated experimentally. Without experimental testing on a hardware system, modeling and numerical simulation efforts are still insufficient to capture and understand the SOFC/GT transient response and operational challenges that may help in developing control strategies.

Previous studies considered hybridizing gasifier technologies for biomass, syngas, and liquid fuels to exploit the SOFC fuel flexibility benefits $[1,2]$. The influences of fuel gas compositions on the total system efficiency, economic, and thermodynamic feasibility in a specific SOFC hybrid system design are among active research topics in most studies [1, 18-20]. Previous work has also considered the consequences of internal reforming systems and external reforming systems, which were driven by the use of natural gas or methane [21]. However, the studies on fuel flexibility of SOFC/GT hybrid systems were all conducted via modeling and numerical simulations at steady state conditions. It is clear that transient performance of SOFC/GT and controls development are much less commonly studied, primarily due to the lack of available experimental data [22, 23].

Motivated by the existing gaps, this work aims to experimentally investigate the effects of fuel composition variation in the SOFC/GT hybrid, the coupling mechanisms between each SOFC variable, and to identify the potential challenges in fuel flexible operations and controls. The findings presented in this paper were uniquely collected using hardware-based simulations of an SOFC/GT to support future development of more realistic dynamic controls for thermal management under fuel flexible environments. In this paper, the experimental evidence of SOFC/GT dynamic performance in response to fuel composition transients is 
presented, followed by a characterization of transient trajectory for each key process variable. First, we ran the test without using any controller in the system such that the results could provide understanding of the actual transient impact on fuel cell temperature. Second, we repeated the same test with a turbine speed controller to compare and investigate the influence of cathode air mass flow during fuel composition dynamics. We found that the effects on fuel cell temperature mainly drove the dynamics coupling between all SOFC/GT hybrid components and the resulting cathode air mass flow fluctuation could be the linking event in the initial dynamic response.

\section{Background and Methodology}

Many researchers selected cathode air mass flow as a critical manipulated variable for SOFC thermal management in hybrid systems because the impact of cathode air mass flow on temperature dynamics was significantly strong and fast [7, 24]. Cathode air mass flow control was used for various objectives, including during start-up, power output control [25, 26], load following [27, 28], or part load operations [29, 30]. Cathode air mass flow was manipulated to minimize spatial temperature variation and to maintain the average stack temperature such that thermal stress in the cell could be avoided [14, 24, 31]. However, fuel composition effects were not considered in the thermal management and control development due to limited studies in fuel composition transients.

Motivated by the unknown transient behaviors of the SOFC/GT hybrid systems under fuel dynamics, we started investigating the impacts of a step change from methane lean syngas to $14 \mathrm{~mol} \% \mathrm{CH}_{4}$ and $86 \%$ steam in a closed loop experiment [17]. Note that this paper distinguished between closed loop and open loop based on turbine speed control implementation. Closed loop referred to the operation with turbine speed control, where the turbine speed was maintained constant by placing variable loads on the turbine shaft. As such, the system was operated at approximately constant cathode air mass flow [9, 17]. In contrast, open loop referred to the operation that did not use the turbine speed control, which allowed the system to have variable turbine speed at a fixed shaft load. The closed loop case was beneficial to test the system within very minimal disturbance and failure risk since the actual response was unknown. The turbine speed control also allowed decoupling the effects of cathode air mass flow variation resulted from the fuel composition dynamics.

Although the main scope of this paper concerns open loop system characterization, closed loop tests were performed as well for comparison purposes. The step tests presented in this study were slightly different from the previous work $[9,17]$; in this work, the fuel feed was given a step change from the same methane lean syngas composition as given in Table 1 to $13.6 \mathrm{~mol} \%$ methane and $86.4 \%$ steam. This is because scoping studies using 14 mol\% methane and $86 \%$ steam in open loop (with no turbine speed controller) led to dangerous circumstances and premature stoppage since the turbine quickly approached the turbine speed safety limit [32]. However, lowering the target methane content by only $3 \%$ to a composition of $13.6 \mathrm{~mol} \% \mathrm{CH}_{4}, 86.4 \%$ steam resulted in a stable turbine speed in open loop with no safety violations. Therefore, in this work, none of the results of the previous work could be used for comparison purposes, and so both open loop and closed loop studies using 13.6 mol\% methane step targets were conducted for this work.

The drastic composition switch from methane lean-syngas to the humidified methane content was considered in this work to provide insights of the hybrid system performance at the maximum operational limits. The step change was used to represent the "worst case possible" in composition variations, which involved significant changes in each fuel component. It was expected that the effects of fuel composition could provide a broad generality in terms of qualitative assessment, including the sensitivity of methane content. This information was critical for the development of dynamic controls in the hybrid system.

\subsection{Description of Cyber-physical Simulation System}

The U.S Department of Energy, National Energy Technology Laboratory (NETL) in Morgantown, West Virginia developed a Hybrid Performance (Hyper) project test facility to characterize SOFC/GT hybrid systems for dynamic control development using a cyber-physical fuel cell system. The Hyper project, as shown in Figure 2, was used to investigate system transient capabilities that are associated with feasible dynamic operating ranges, coupling effects between fuel cell subsystem and recuperated gas turbine cycle, and highly complex dynamic control strategies [15, 16, 33-35].

In the Hyper project, a previously developed real-time dynamic model (in the dotted box in Figure 2) was coupled to real hardware to emulate SOFC dynamic performance. We used a one-dimensional (1D) dynamic model that was able to simulate the SOFC every $30 \mathrm{~ms}$ [36]. This cyber-physical fuel cell system was then hybridized with a real recuperated gas turbine cycle in a direct-fired configuration [5, 36]. A $120 \mathrm{~kW}$ Garret Series 85 auxiliary power unit (APU) were employed, consisting of a single-shaft gas turbine (T101), operating at a nominal 40,500 rpm, a two-stage compressor (C100), and a 400Hz gear-driven generator (G102). 
The compressor was designed to deliver about $2 \mathrm{~kg} / \mathrm{s}$ at a pressure ratio of 4 . The nominal temperature of the compressor discharge was approximately $475 \mathrm{~K}$ for an inlet temperature of $298 \mathrm{~K}$. For turbine speed control, an isolated $120 \mathrm{~kW}$ resistor bank (E105) was used in the system to put adjustable resistive load on the turbine shaft. The nominal conditions of the gas turbine cycle during the tests are summarized in Table 1.

Various sensors and actuators were mounted in the hardware system to measure pressure, mass flow, temperature, and turbine rotational speed. The measurement for turbine speed was provided by three optical sensors but only average speed was presented in this work. The detailed specification of the main sensors and actuators are listed in Table 2 . The cathode stream was physically provided in the hardware system using the compressor flow, while the anode fuel stream was simulated in the model. Real-time measurement from TE326, FT380, and PT305 (Figure 2) were used as the model inputs for cathode inlet conditions, respectively for air temperature, mass flow, and pressure. Both hardware and software were well-integrated for real time hardwarebased simulations to closely represent SOFC/GT hybrid transients for controls development.

State of the art computer simulation is currently unable to capture the dynamic behavior of hybrid systems with high fidelity, because of the physical size, complexity, and widely spread time scales in the system. Use of cyber-physical simulation enables controls system research and testing, over an operating space that would risk costly damage to a solid oxide fuel cell, without actually putting a fuel cell at risk. Combining the fuel cell real-time simulation with a real gas turbine captures the fast dynamic behavior that is critical for realistic controls research.

The real-time SOFC model used in this study was developed based on a planar design, co-flow, and anode-supported fuel cell configuration. A standard material using 441 stainless steel was considered for interconnects, while nickel-doped yttria-stabilized zirconia (Ni-YSZ), YSZ- lanthanum strontium magnetite (LSM), and YSZ were used as anode, cathode, and electrolyte, respectively. This numerical model characterized the fuel cell performance on a cell distributed basis with respect to space in the direction of fuel and oxidant flow [36]. In this model, fuel processing unit was not considered. Thus, it was assumed that the fuel was supplied at the desired operating temperature and pressure. Fuel constituents fed into the system model could be a combination of $\mathrm{CH}_{4}, \mathrm{CO}, \mathrm{CO}_{2}, \mathrm{H}_{2}, \mathrm{H}_{2} \mathrm{O}$, and $\mathrm{N}_{2}$, assuming hydrogen was the only electrochemically active component for hydrogen oxidation, as expressed in Eq. 1. $\mathrm{CO}$ and $\mathrm{CH}_{4}$ direct electrochemical oxidation were assumed negligible in this study due to their slow kinetics, slow mass transfer to the triple-phase boundary (TPB), and less active area available for electrochemical oxidation [37].

Pressure loss across the fuel cell was not considered. The direct internal reforming reaction of methane based on the first-order kinetic and water-gas shift reaction for carbon monoxide were considered in the model, according to Eq. 2 to Eq. 5. Considering the faster kinetics of the water-gas shift reaction compared to methane reforming kinetics at the temperature range used in this study, the shifting reaction was assumed to occur at equilibrium [37]. The equilibrium constant for water-gas shift was resolved by Eq.3, where $p_{i}$ is the partial pressure of component $i, x_{i}$ is the mole fraction of component $i$, and $T$ is the solid temperature in Kelvin. In Eq. 5, $A_{r x}$ is a pre-exponential factor, $T$ is the fuel cell solid temperature, and $R_{u}$ is the ideal gas constant.

Hydrogen electrochemical oxidation:

$\mathrm{H}_{2}+\mathrm{O}^{=} \rightarrow \mathrm{H}_{2} \mathrm{O}+e^{=}\left(\Delta H^{\circ}=-286 \mathrm{~kJ} / \mathrm{mol}\right)$

Water-gas shifting:

$\mathrm{CO}+\mathrm{H}_{2} \mathrm{O} \rightleftharpoons \mathrm{H}_{2}+\mathrm{CO}_{2} \quad\left(\Delta \mathrm{H}^{\circ}=-41 \mathrm{~kJ} / \mathrm{mol}\right)$

$K_{P, W G S}=\frac{P_{\mathrm{H}_{2}} P_{\mathrm{CO}_{2}}}{P_{\mathrm{H}_{2} \mathrm{O}} P_{\mathrm{CO}}}=\frac{x_{\mathrm{H}_{2}} x_{\mathrm{CO}_{2}}}{x_{\mathrm{H}_{2} \mathrm{O}} x_{\mathrm{CO}}}=\exp \left[\frac{4276}{T}-3.961\right]$

Steam methane reforming:

$\mathrm{CH}_{4}+\mathrm{H}_{2} \mathrm{O} \rightleftharpoons 3 \mathrm{H}_{2}+\mathrm{CO}\left(\Delta \mathrm{H}^{\circ}=206 \mathrm{~kJ} / \mathrm{mol}\right)$

$r_{S M R}=4274 \frac{\mathrm{mol}}{s \cdot m^{2} \cdot b a r} p_{C H_{4}} \exp \left[\frac{-82,000^{J} / \mathrm{mol}}{R_{u} T}\right] A_{r x}$

In general, the model incorporated dynamic calculation for thermal performance (heat generation, solid and gas temperature profiles), electrochemical characterization (Nernst potential, polarization losses, current density, and voltage), anode composition gradients, and associated fuel cell variables (power, fuel cell post combustor thermal effluent, etc.). Finite difference and finite volume were respectively used for the resolution of thermal profiles, and electrochemical performance. The model was successfully verified and validated against International Energy Agency (IEA) benchmarking data sets, and other simulation studies [36]. 


\subsection{Open Loop and Closed Loop Test Procedures}

In this study, the standard startup procedures established by NETL researchers was used to bring the hybrid system to a steady state for cyber physical simulations [38]. Methane lean syngas was fed as the initial SOFC fuel at $145 \mathrm{~g} / \mathrm{s}$. The corresponding initial fuel utilization was approximately $67 \%$. A step change in SOFC fuel composition from the syngas feed to methane-rich gases was simulated once the system was in steady state. The methane-rich fuel contained $13.6 \mathrm{~mol} \% \mathrm{CH}_{4}$ and $86.4 \%$ steam, which was sufficient to avoid carbon deposition in the cell $[7,39]$.

Fuel flow (145 g/s) and SOFC load (220 A) were held constant over the course of the experiment to investigate the impacts of fuel composition uniquely, without confounding the data with the dynamic impacts of fuel flow and SOFC load. In contrast, overall fuel utilization was the result in this study that changed accordingly to fuel composition gradients. The fuel switch was simplified by changing the feed composition to the SOFC model instantaneously, not taking into account the lag in the fuel manifold subsystem.

Such a fuel transition caused a $20 \%$ decrease in overall heat input (LHV) of the anode feed. This change was feasible for open loop tests in which turbine speed control was not implemented [17, 32]. Previous scoping studies suggested that the methane lean syngas had to be switched to a lower heating value methane rich fuel in order to avoid turbomachinery stall and surge, excessive anode-cathode pressure differences, and cathode inlet temperature excursions resulting in adverse impacts on the functionality of SOFC/GT hardware facility [17].

For the purposes of comparison, the test procedures and conditions used for the open loop tests and the closed loop tests in this work were identical, including fuel compositions, initial conditions of SOFC/GT hybrid test facility, cell geometry, and hardware operation techniques. However, unlike the closed loop studies where a control system placed a modulated electrical load (or resistive turbine load) on the turbine shaft to maintain constant turbine speed at 40,500 rpm, no turbine speed control scheme was used in the open loop tests. Thus, the turbine responded directly to the total SOFC system post combustor thermal output (i.e. fuel cell thermal effluent). The heat was delivered to the turbine inlet in real time as shown in Figure 2.

In this work, the 1D real-time SOFC model calculated the SOFC waste heat at every 80 ms simulation time step, considering inlet conditions of the cathode stream in the plant, user-defined inputs, and fuel cell geometry described in Table $1[36,40]$. In our cyber-physical simulations, the resulting waste heat was used to control a Swift fuel valve position, FV432 (Figure 2), in feed-forward mode. The fuel valve opened accordingly to deliver an equivalent natural gas flow to simulate the waste heat delivered to the real gas turbine cycle. The Swift valve is $2.54 \mathrm{~cm}$ sonic needle and nozzle operated at high speed with a steeper motor, enabling measurement of fast natural gas flow changes. 
Table 1 SOFC/GT parameters and initial operating conditions

\begin{tabular}{|c|c|}
\hline \multicolumn{2}{|l|}{ System parameter } \\
\hline Fuel cell load & $220 \mathrm{~A}$ \\
\hline Anode recycle & $0 \%$ \\
\hline Initial fuel cell temperature & $800^{\circ} \mathrm{C}$ \\
\hline Total cell area & $200 \mathrm{~mm} \times 200 \mathrm{~mm}$ \\
\hline Anode thickness & $0.5 \mathrm{~mm}$ \\
\hline Electrolyte thickness & $0.008 \mathrm{~mm}$ \\
\hline Cathode thickness & $0.05 \mathrm{~mm}$ \\
\hline Oxidant/fuel channel size & $2 \mathrm{~mm} \times 2 \mathrm{~mm}$ \\
\hline Stack size & 2500 cells \\
\hline Total stack mass & $3500 \mathrm{~kg}$ \\
\hline Total stack heat capacity & $2625 \mathrm{~kJ} / \mathrm{K}$ \\
\hline \multicolumn{2}{|l|}{ Fuel cell cathode inlet condition } \\
\hline Air mass flow rate & $1.03 \mathrm{~kg} / \mathrm{s}$ \\
\hline Air temperature & $705^{\circ} \mathrm{C}$ \\
\hline Air pressure & $347 \mathrm{kPa}$ \\
\hline Air composition & $21 \% \mathrm{O}_{2}, 79 \% \mathrm{~N}_{2}$ \\
\hline \multicolumn{2}{|l|}{ Fuel cell anode inlet condition } \\
\hline Fuel mass flow rate & $145 \mathrm{~g} / \mathrm{s}$ \\
\hline Fuel temperature & $800^{\circ} \mathrm{C}$ \\
\hline Fuel pressure & $347 \mathrm{kPa}$ \\
\hline Initial fuel composition - methane & $\mathrm{CH}_{4} 0 \%, \mathrm{CO}_{2} 12.0 \%, \mathrm{CO} 28.6 \%$, \\
\hline lean syngas (mol fraction) & $\mathrm{H}_{2} 29.1 \%, \mathrm{H}_{2} \mathrm{O} 27.1 \%, \mathrm{~N}_{2} 3.2 \%$ \\
\hline $\begin{array}{l}\text { Final fuel composition - humidified } \\
\text { methane (mol fraction) }\end{array}$ & $\mathrm{CH}_{4} 13.6 \% / \mathrm{H}_{2} \mathrm{O} 86.4 \%$ \\
\hline \multicolumn{2}{|l|}{ Fuel cell initial condition } \\
\hline Cell voltage & $0.83 \mathrm{~V}$ \\
\hline Fuel utilization & $67 \%$ \\
\hline \multicolumn{2}{|l|}{ Gas turbine initial conditions } \\
\hline Turbine load & $40 \mathrm{~kW}$ \\
\hline Turbine speed & $40,500 \mathrm{rpm}$ \\
\hline \multirow[t]{2}{*}{ Turbine inlet temperature } & 1086 K (Open loop) \\
\hline & $1070 \mathrm{~K}$ (Closed loop) \\
\hline \multirow[t]{2}{*}{ Turbine outlet temperature } & $808 \mathrm{~K}$ (Open loop) \\
\hline & 795 K (Closed loop) \\
\hline \multicolumn{2}{|l|}{ Compressor initial conditions } \\
\hline Compressor inlet flow & $1.95 \mathrm{~kg} / \mathrm{s}$ \\
\hline Compressor inlet temperature & 296 K (Open/Closed loop) \\
\hline Compressor outlet temperature & 464 K (Open/Closed loop) \\
\hline Pressure ratio & 3.6 \\
\hline
\end{tabular}

\begin{tabular}{|c|c|c|c|}
\hline Instrument & Measured variable & Rangeability & Error \\
\hline $\begin{array}{l}\text { ST-502 } \\
\text { Optical sensor } 1200 \mathrm{~Hz}\end{array}$ & $\begin{array}{l}\text { Turbine speed } \\
\text { (T101) }\end{array}$ & $0-50,000 \mathrm{rpm}$ & $\begin{array}{c}\text { standard deviation of } 50 \mathrm{rpm} \\
\text { on } 40,500 \mathrm{rpm}(0.12 \%)\end{array}$ \\
\hline $\begin{array}{l}\text { PT-151 } \\
\text { Pressure transducer }\end{array}$ & $\begin{array}{l}\text { Compressor }(\mathrm{C} 100) \\
\text { discharge pressure }\end{array}$ & 0 - $552 \mathrm{kPag}$ & $0.29 \%$ \\
\hline $\begin{array}{l}\text { PT-305 } \\
\text { Pressure transducer }\end{array}$ & $\begin{array}{l}\text { Cathode (V301) } \\
\text { inlet pressure }\end{array}$ & 0 - $400 \mathrm{kPag}$ & $0.27 \%$ \\
\hline $\begin{array}{l}\text { TE-326 } \\
\text { Thermocouple }\end{array}$ & $\begin{array}{l}\text { Cathode (V301) } \\
\text { inlet temperature }\end{array}$ & $0-1,100^{\circ} \mathrm{C}$ & $0.01 \%$ \\
\hline $\begin{array}{l}\text { FT-380 } \\
\text { Annubar flow meter }\end{array}$ & $\begin{array}{l}\text { Cathode (V301) } \\
\text { inlet mass flow }\end{array}$ & $0-3 \mathrm{~kg} / \mathrm{s}$ & $0.7 \%$ \\
\hline
\end{tabular}




\section{Results and Discussion}

\subsection{Turbine Speed and Cathode Air Mass Flow Transient Responses}

The trajectories of turbine speed and cathode inlet mass flow for the open loop and the closed loop tests in response to fuel composition changes are shown in Figure 3. The time at which the step change in fuel composition occurred is indicated as time $\mathrm{t}=0$. For the open loop case, the turbine speed varied depending on the changes in fuel cell thermal effluent.

As shown in Figure 3a, a 4\% increase in turbine speed immediately after the step change in fuel composition caused an $8 \%$ initial transient increase in cathode air mass flow as presented in Figure $3 \mathrm{~b}$. This was followed by a steady decrease to a new steady state with the turbine speed $6 \%$ lower and the cathode air flow rate $12 \%$ lower than it was at the initial condition. The turbine speed varied in response to the resulting changes in the fuel cell thermal effluent during fuel composition dynamics. Such transients ultimately caused perturbations in cathode inlet air mass flow, which in turn, affected the stack performance. The cause-and-effect in the hybrid dynamic performance was discussed hereafter to show that there were strong coupling effects between the gas turbine cycle and the fuel cell.

Figure $3 \mathrm{c}$ shows that the cathode inlet air mass flow was linearly correlated to the turbine speed with a factor of 2:1 ( $\mathrm{R}^{2}=0.993$ on a normalized comparison of the measurements) at any given time. For comparison, the results from the closed loop test for the same transition is also shown in Figure 3 . In the closed loop test, the turbine speed was controlled at a constant 40,500 rpm. The "crossover point," the point at which the open loop and the closed loop values were the same, for both variables is at around 1,600 s after the step change. In this paper, crossover point was used to characterize the influence of open and closed loop operations on the transient response. Delay in crossover points were investigated to identify the coupling effects between all SOFC/GT process variables, which is critical developing control strategies for non-linear responses.
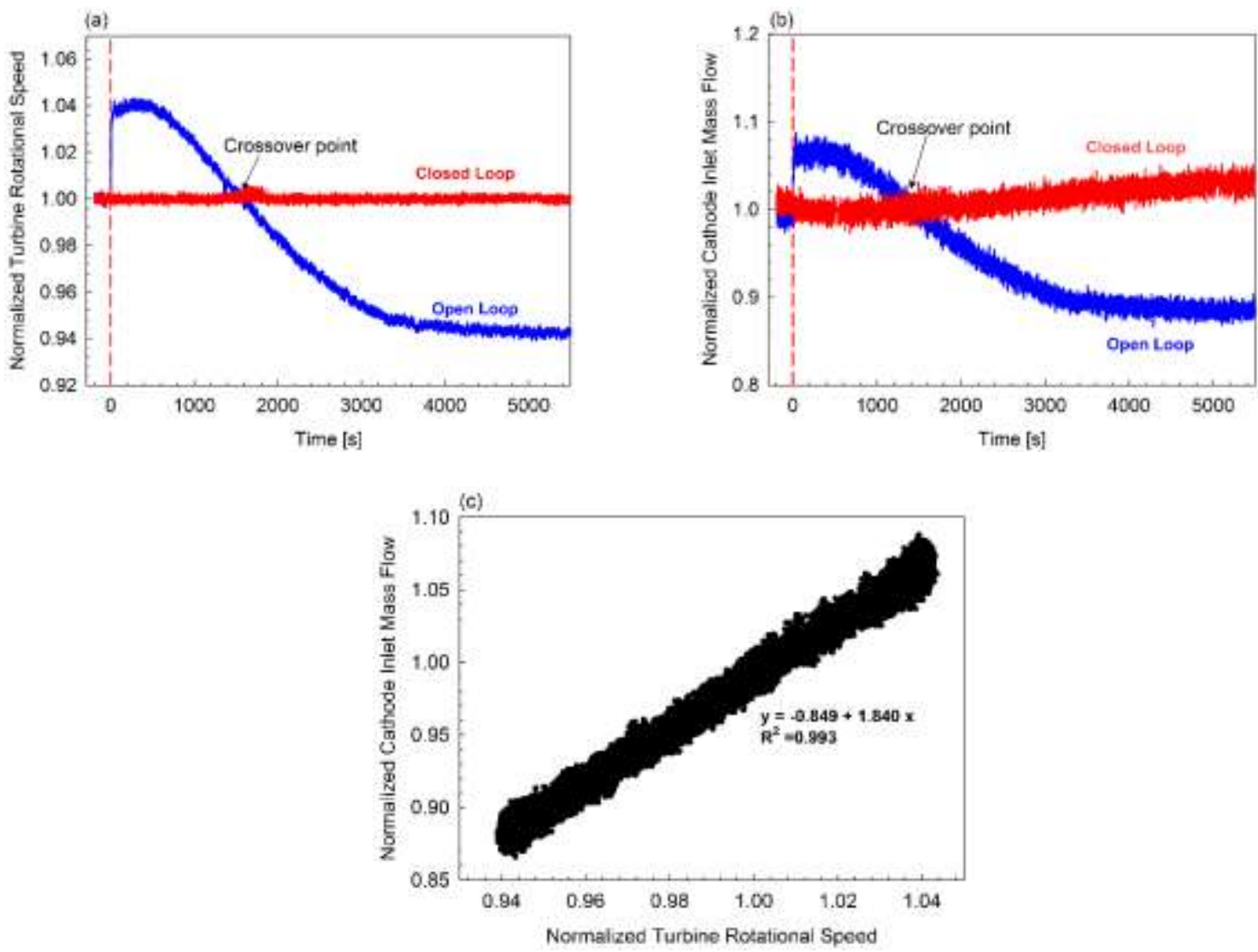


\subsection{Transient Characterization of Fuel Cell Thermal Performance}

\section{Fuel Cell Solid Temperature}

The transients of the fuel cell solid temperature are shown in Figure $4 \mathrm{a}$ and $4 \mathrm{~b}$. In general, the fuel cell solid temperatures for both the open loop (Figure 4a) and closed loop (Figure 4b) increased across the fuel cell length. However, the temperature reduced with time to a lower final average temperature as the test continued over the course of 5,500 s. In the open loop test, the temperature difference between the cell inlet and the cell exit was $125^{\circ} \mathrm{C}$ at the initial steady state, before the fuel composition change and also at the final steady state after the fuel composition change. The same inlet to outlet temperature difference across the cell was observed in both cases, but a lower average temperature at the final steady state was realized due to the higher airflow in the closed loop case.
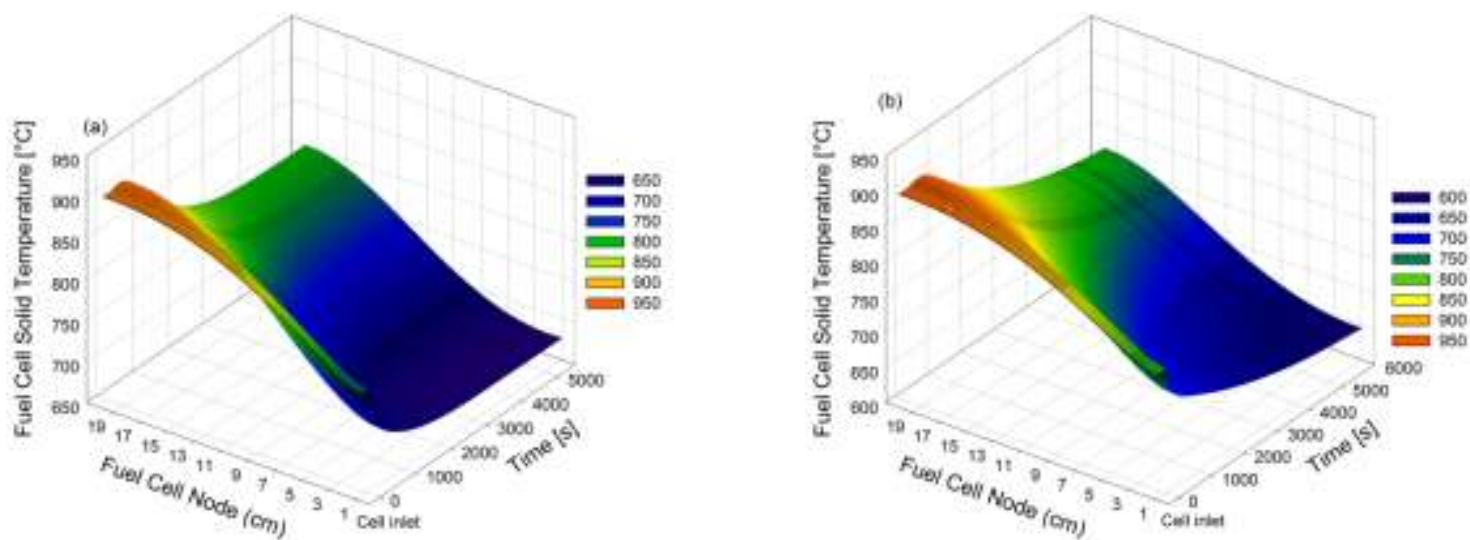

Figure 4: Fuel cell solid temperature as a function of time, (a) Open loop (b) Closed loop

Figure 5a shows the distributed profiles of solid temperature at certain times, resulting from the open loop and closed loop tests. Figure $5 \mathrm{~b}$ highlights the magnitude of difference between the open loop and closed loop solid temperature profiles over $5,500 \mathrm{~s},\left(T_{\text {solid }_{C L}}-T_{\text {solid }_{O L}}\right)$, for selected nodes.

Although both the open loop and closed loop tests started at the same initial states, indicated by the overlapping profile at $1 \mathrm{~s}$ in Figure 5a, the solid temperature in the closed loop test was generally higher than in the open loop over the first 2,450 s. The greatest temperature difference between the open loop and closed loop occurred at node 2 within the first $650 \mathrm{~s}$ (Figure 5b) because solid temperature in the open loop test dropped substantially. This transient was driven by rapid increase in turbine speed in the open loop case that increased cathode air mass flow to the maximum value, on the order of few seconds after the fuel composition changes. Therefore, the fuel cell solid was further cooled in the open loop case, in addition to direct influence of steam methane reforming. As a result, the temperature decreased faster than in the closed loop case, which was more evident at the beginning of the cell. This effect was shown by the increasing temperature gaps between the open loop and closed loop cases up to 1,500 s.

As indicated in Figure 5b, the location of the greatest temperature difference shifted further from node 2 to node 10 , at point $\mathrm{A}$. At this time, the decrease in the open loop solid temperature half way down the fuel cell length became more significant even though turbine speed and cathode air mass flow shown in Figure 3 started to reduce from the maximum values. Decreasing cathode air mass flow should have mitigated fuel cell solid temperature reduction. However, the cooling effects were still significant because the total cathode air mass flow in the open loop system was still higher than in the closed loop, and the temperature dynamics were slow. The maximum temperature difference of $17^{\circ} \mathrm{C}$ (point B) was observed at node 10 at $1,300 \mathrm{~s}$ after the fuel composition change. After the crossover in turbine speed at $1,600 \mathrm{~s}$, the reduction in fuel cell solid temperature continued slowly with the subsequent cathode air mass flow reduction until the temperature crossover point was reached. 

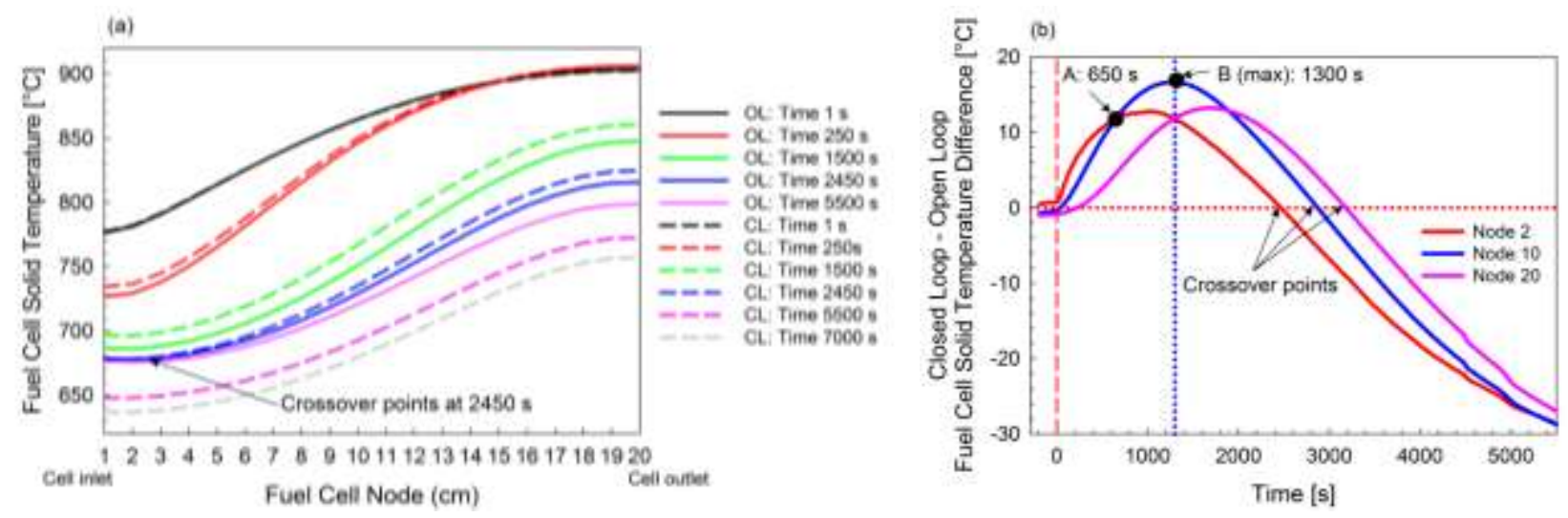

Figure 5: Comparison of fuel cell solid temperature performance, between the open loop and the closed loop tests (a) Distributed data as a function of time, and (b) The response of solid temperature difference at selected fuel cell nodes

It is shown in Figures $5 \mathrm{a}$ and $5 \mathrm{~b}$ that crossover points of solid temperature at the beginning of the cell were achieved at 2,450 s after the step change, whereas the crossover points for the end of the cell were delayed 12 minutes later than the cell entrance. Such a significant difference in crossover points between the cell entrance and the cell exit was dominated by the resulting temperature profiles from the open loop and closed loop tests, indicating coupling between the temperature reduction due to convective heat transfer and methane reforming kinetics. In general, the increased cathode air mass flow before the crossover point of turbine speed caused the decreased in solid temperature, which finally decelerated the reforming reaction. As a result, this modified the distribution of methane in the fuel cell, which in turn, affected the solid temperature.

The comparison shown in Figure 5a demonstrated a greater drop in the closed loop solid temperature after the crossover points. The solid temperature in the closed loop test kept decreasing until 7,000 s after the fuel composition switch, at which the test was terminated. Unlike the open loop process, the constant cathode air mass flow provided by the constant turbine speed operation in closed loop continued to propagate the reduction in fuel cell solid temperature throughout the test. This was clearly reflected by cathode inlet temperature profiles shown in Figure 6.

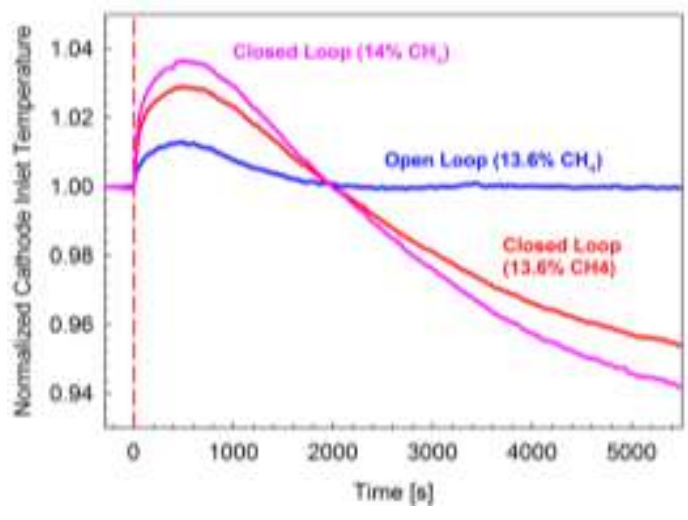

Figure 6: Cathode inlet temperature profiles for the open loop test using $13.6 \mathrm{~mol} \% \mathrm{CH}_{4}$ and for the closed loop operations using $13.6 \mathrm{~mol} \% \mathrm{CH}_{4}$ and $14 \mathrm{~mol} \% \mathrm{CH}_{4}$

In contrast, the open loop temperature did not change significantly after 3,000 s from the start of the test because cathode air mass flow decreased continuously after the crossover point. The operation with variable turbine speed consequently brought the system close to a thermal equilibrium state faster than the closed loop system. Because of the variations in cathode air mass flow, the system demonstrated two distinct and opposite coupling trends in the short-term period and the long-term period. This non-linear response of temperature to composition changes suggests that complex controls in thermal management are required to take advantage of the inherent flexibility of hybrid systems. 


\section{Spatial Gradient of Fuel Cell Solid Temperature}

The distribution of the temperature gradient $(d T / d x)$ for 20 nodes resulting from the open loop test is shown in Figure 7a, while the maximum spatial temperature gradients at critical nodes for open loop and closed loop tests are presented in Figure 7b. Note that the cell temperature distribution should be maintained as constant as possible such that the temperature gradient could be minimized to prevent thermal stress in fuel cell components. The mechanical strength of each SOFC material varied, depending on the thermal expansion properties. Depending on fuel compositions, cell geometries, and operating conditions, a range between $4 \mathrm{~K} / \mathrm{cm}$ to $12 \mathrm{~K} / \mathrm{cm}$ was considered as an acceptable $d T / d x$ for SOFC load changes [14, 41]. However, the actual $d T / d x$ under fuel composition dynamic was still unknown.

Both tests demonstrated the same variations and locations of the maximum $d T / d x$, as simplified in Figure $7 \mathrm{~b}$. However, the maximum $d T / d x$ resulting from the open loop test were slightly higher than in the closed loop. Before fuel composition was switched in the open loop operation, the highest temperature gradient of $11.7 \mathrm{~K} / \mathrm{cm}$ occurred at node $5,25 \%$ of the total fuel cell length, and gradually shifted to the next node towards the cell exit after initiation of the transient. The greatest $d T / d x$ of $17 \mathrm{~K} / \mathrm{cm}$ appeared at node $7,35 \%$ of the way down from the inlet, as soon as $500 \mathrm{~s}$ after switching to humidified methane. Adequate thermal management was required since there was high risk of thermal stress due to the high $d T / d x$. The maximum $d T / d x$ was settled at node $13,65 \%$ of the way down the length from the cell entrance, at approximately $1,950 \mathrm{~s}$ after the transient where cathode air mass flow was $4 \%$ below its initial value (Figure $3 b$ ).

As shown in Figure 8, the maximum magnitude of discrepancy in the $d T / d x$ between the open loop and closed loop at node 5 and node 7 , were about $1 \mathrm{~K} / \mathrm{cm}$ at $1,600 \mathrm{~s}$, and $1 \mathrm{~K} / \mathrm{cm}$ difference at node 13 , at $650 \mathrm{~s}$ after the transient. As presented in Figure 9, the increasing difference in $d T / d x$ for all three nodes were evident within the first $650 \mathrm{~s}$ (region I), which respectively collocated with increasing cathode air flow, before the crossover point. Note that cathode air flow in the open loop test started to decrease in region II approaching the initial condition and continued to reduce more significantly below the initial condition in region III.
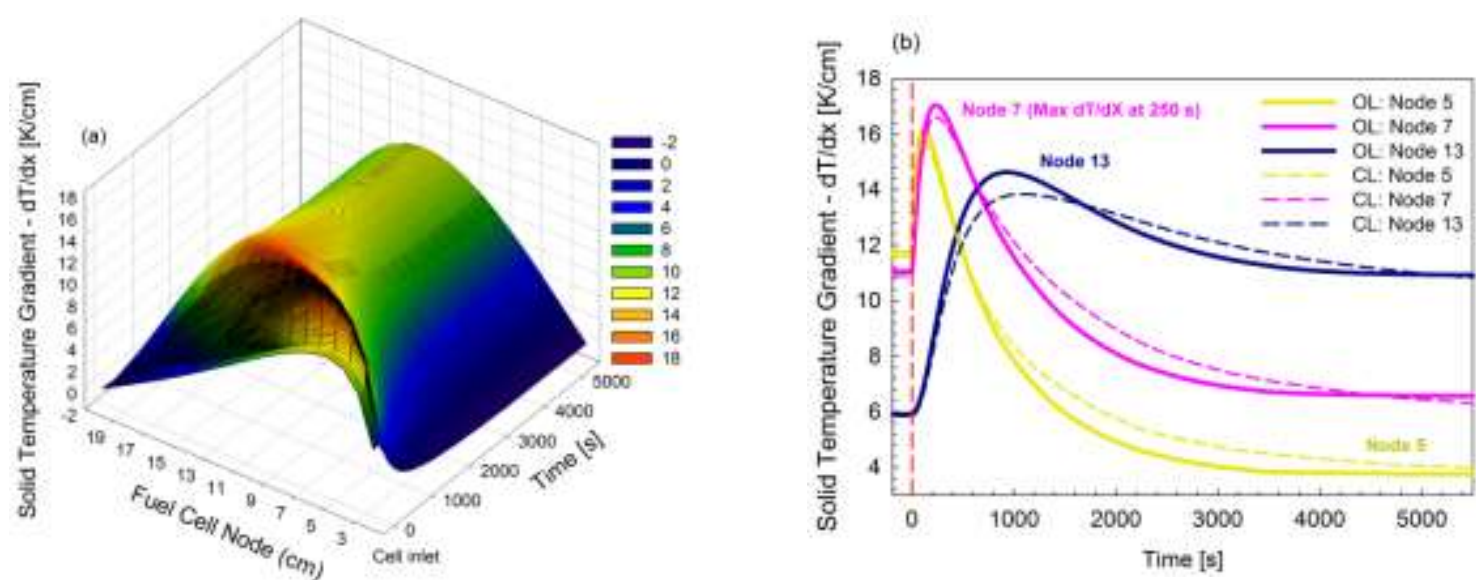

Figure 7: Spatial temperature gradient as a function of time, (a) Open loop transient response (b) Comparison of open loop and closed loop solid temperature gradients at critical nodes

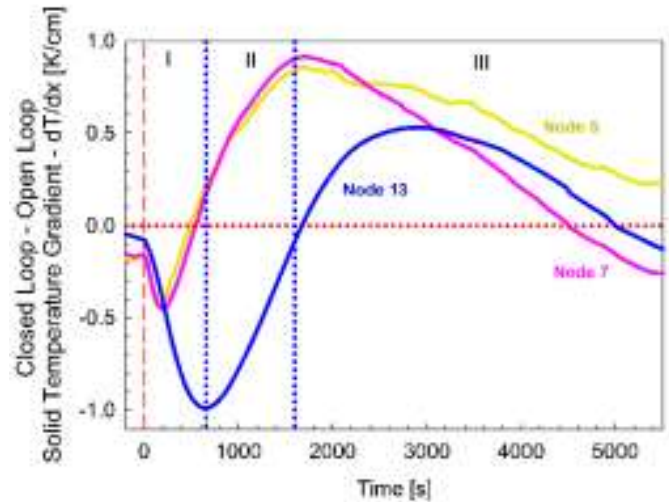

Figure 8: The difference in solid temperature gradient at critical nodes 
Cathode Gas Temperature

The dynamic transients of the fuel cell gas temperature are illustrated in Figure 9. As clearly shown in Figure 9b, there was significant deviation in fuel cell gas temperature at the beginning of the cell between the open loop and closed loop profiles at $250 \mathrm{~s}$. This transient was attributed to the combined effects of cathode air mass flow and cathode inlet air temperature. Both tests demonstrated the initial transient rise in cathode inlet air temperature in response to fuel composition changes (Figure 6). However, the open loop performance shown in Figure 6 experienced 1\% increase, while the closed loop case experienced 3\% increase. This difference in temperature increase existed in spite of the higher turbine inlet temperature of the open loop operation because turbine efficiency in the open loop improved at the higher speeds [32]. As such, turbine exhaust temperature in open loop case was lower because the increase in turbine exhaust temperature was not as significant as the increase in turbine inlet temperature. As a consequence of the lower cathode air mass flow with higher cathode inlet air temperature, gas temperature of the closed loop test at the cell entrance was higher than the open loop system at $250 \mathrm{~s}$.

Figure 10 shows the fuel cell gas temperature difference at the beginning, center, and exit of the cell. Over 5,500 s of test, the magnitude of gas temperature difference across the fuel cell length varied significantly due to fluctuations of cathode air mass flow in the open loop case. The long term trends of gas temperature started to twist after the crossover points, similar to the solid temperature dynamics shown in Figure 5. In a longer experimental run, the gas temperature in the closed loop system reduced faster than in the open loop case due to decreased solid temperature and constant cathode air mass flow at a higher level. In contrast, the open loop gas temperature (Figure 9b) changed slowly as cathode air mass flow decreased, leading to insignificant temperature drop between 3,000 s and 5,500 s.
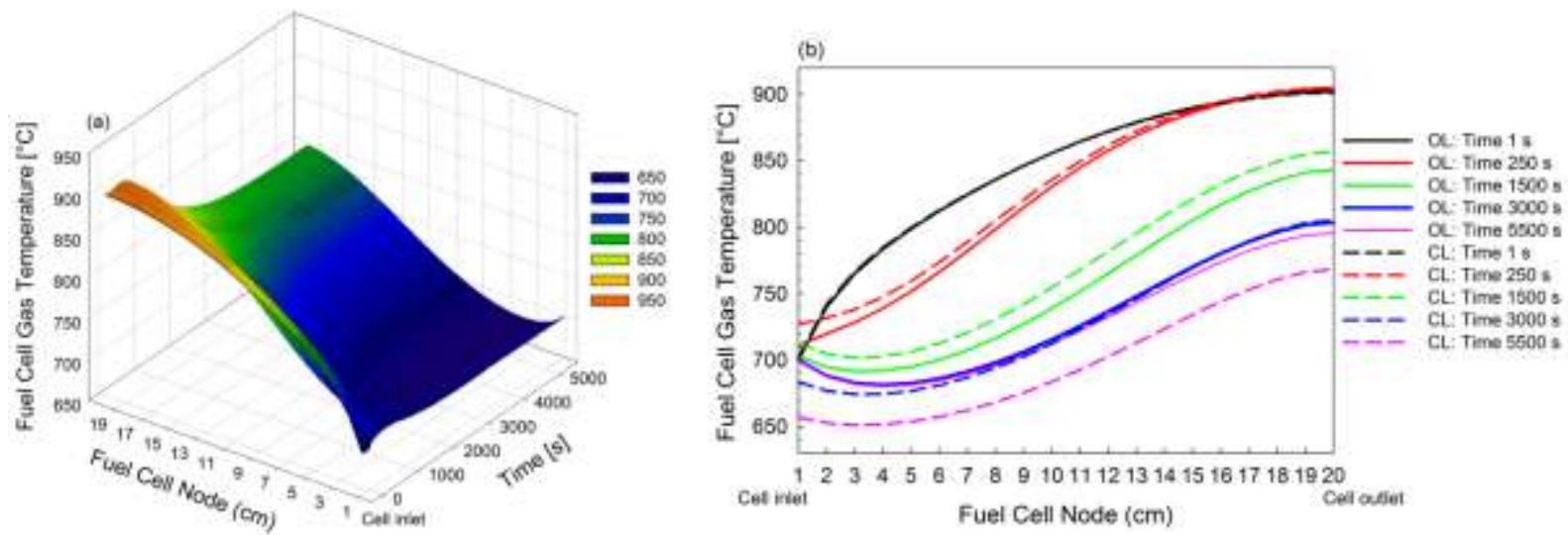

Figure 9: Fuel cell gas temperature as a function of time, (a) Open loop transient response content (b) Comparison of open loop and closed loop transients

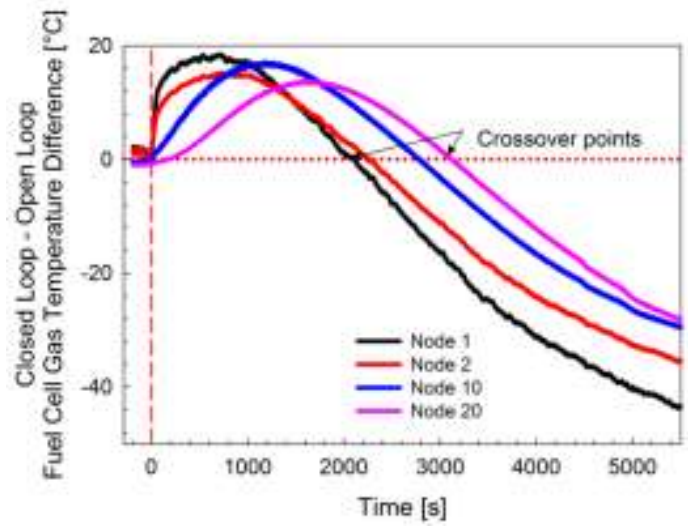

Figure 10: Crossover points in fuel cell gas temperature difference between the open loop and the closed loop for selected local fuel cell positions

\section{Cathode Solid and Gas Temperature Difference and Heat Flux}

Figure 11 shows the resulting temperature difference between fuel cell solid and gas temperature $\left(T_{\text {solid }}-T_{\text {gas }}\right)$. As shown in Figure 11, the temperature difference at the first 5 nodes reduced drastically at the 
initial transients and fluctuated more significantly over the course of the test as compared to the remaining fuel cell length. The temperature difference at the cell inlet shown in Figure $11 \mathrm{~b}$ dramatically reduced from $76^{\circ} \mathrm{C}$ to slightly lower than $-20^{\circ} \mathrm{C}$ within $5,500 \mathrm{~s}$, whereas the temperature difference at the end of the cell was maintained fairly constant.
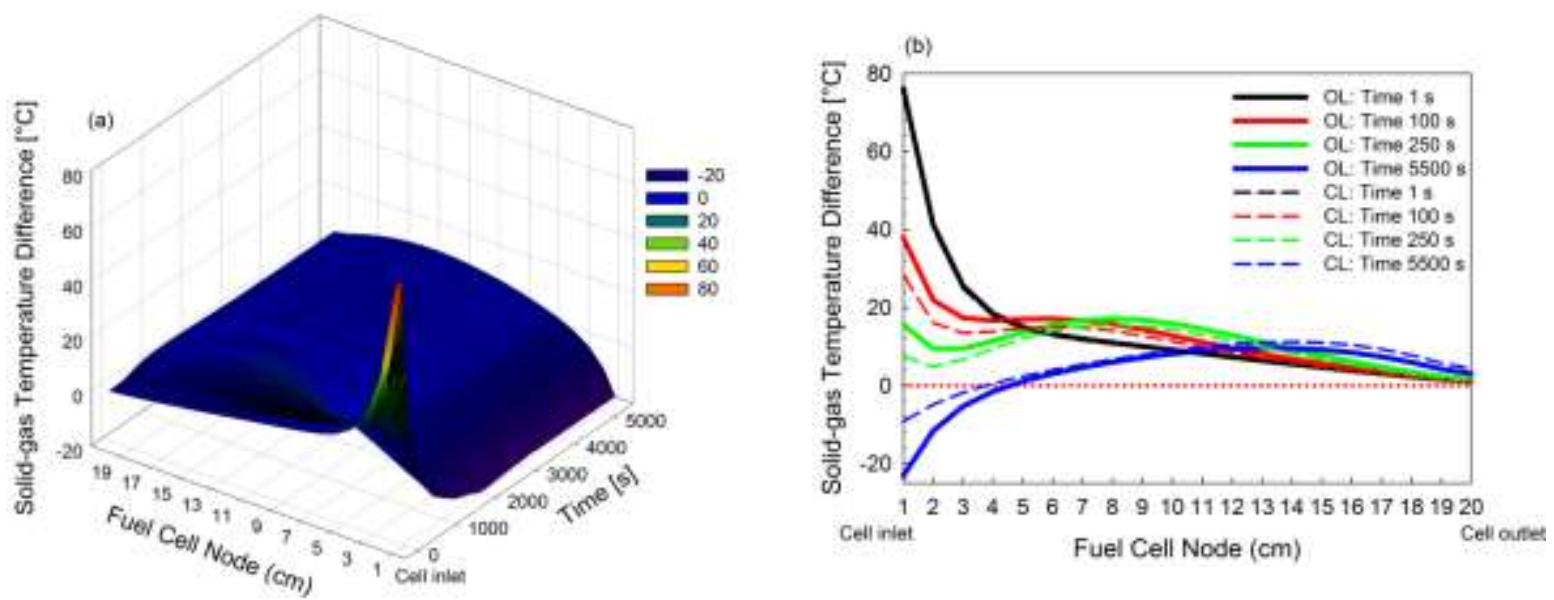

Figure 11: Fuel cell solid-gas temperature difference as a function of time, (a) Open loop transient response, (b) Comparison of open loop and closed loop transients

As can be seen in Figure 11b, the results for the open loop at the beginning of the cell within $250 \mathrm{~s}$ (after the fuel switch) was higher than in the closed loop. This difference was strongly influenced by the increased cathode air mass flow (Figure 3b) and lower cathode inlet air temperature (Figure 6) before the crossover points $(1,600 \mathrm{~s})$. Such transients caused a more remarkable gas temperature drop, as compared to solid temperature drop. Hence, the gas temperature in the open loop reduced faster than the solid temperature, resulting in higher temperature difference. This consequently promoted higher heat flux from the solid to the gas that ultimately propagated the open loop solid temperature decrease. The profiles of heat flux in the fuel cell subsystem are presented in Figure 12. The trends indicated a strong qualitative reflection of the fuel cell solidgas temperature difference, following the correlation expressed in Eq. 6.

Fuel cell heat flux:

$\dot{q}=\frac{k_{g} N u}{D}\left(T_{\text {solid }}-T_{\text {gas }}\right)$

where $k_{g}$ is the thermal conductivity of gas, $N u$ is the Nusselt number, $D$ is the hydraulic diameter of the gas channel, $T_{\text {solid }}$ is the solid temperature, and $T_{\text {gas }}$ is the gas temperature.
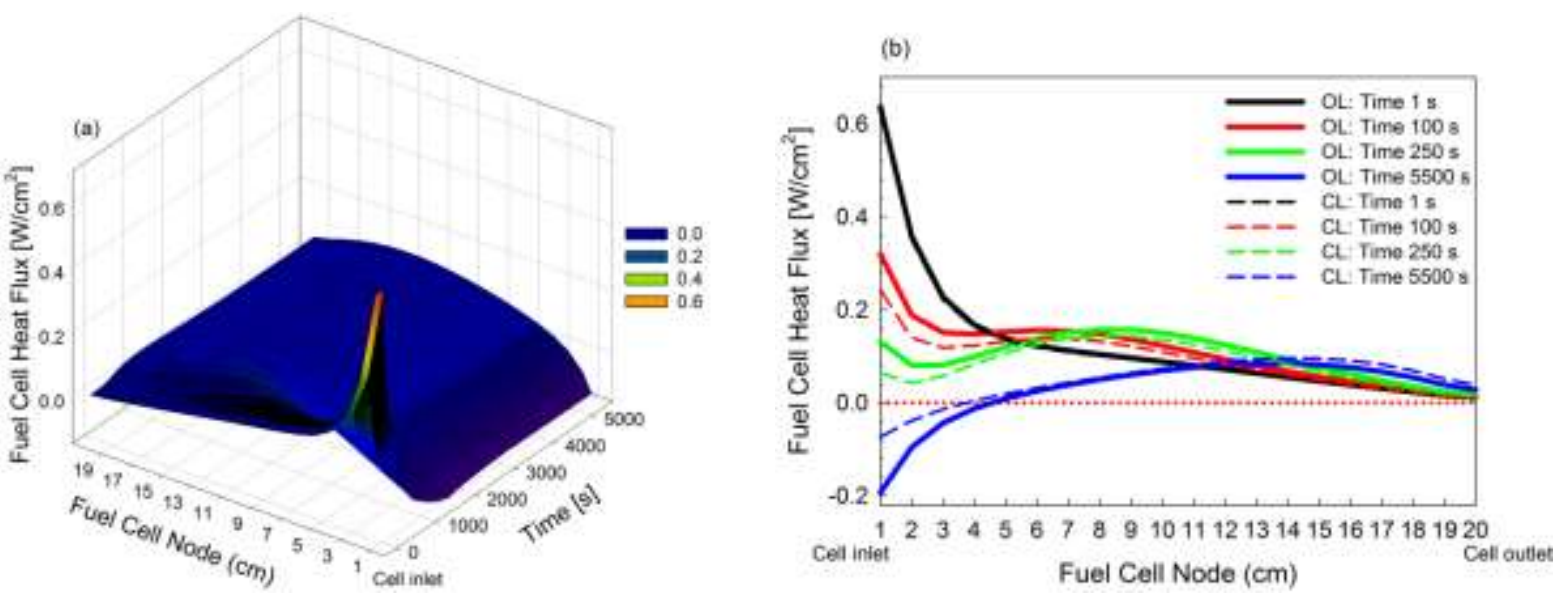

Figure 12: Heat flux of a fuel cell stack as a function of time, (a) Open loop transient response, (b) Comparison of open loop and closed loop transients

The dynamic transients of heat flux at 5,500 s contrasted the initial transient trends. Because of the reversed trends of cathode air mass flow and cathode inlet air temperature after the crossover points, the heat flux in the open loop test was more negative than in the closed loop test. The open loop gas temperature 
increased faster than in the solid temperature such that the solid-gas temperature difference reduced, due to decreasing cathode air mass flow and higher cathode inlet air temperature. In fact, as shown in Figure 11b, the gas temperature at 5,500 s was higher than the solid temperature. Hence, the direction of heat flux in the longterm operation changed from the solid-to-air flow to air flow-to-solid. The air flow began to heat the fuel cell system after $470 \mathrm{~s}$. In general, the magnitude of heat flux in the closed loop case was much lower than the open loop profiles throughout the test despite of the same performance and heating impacts at the beginning of the cell.
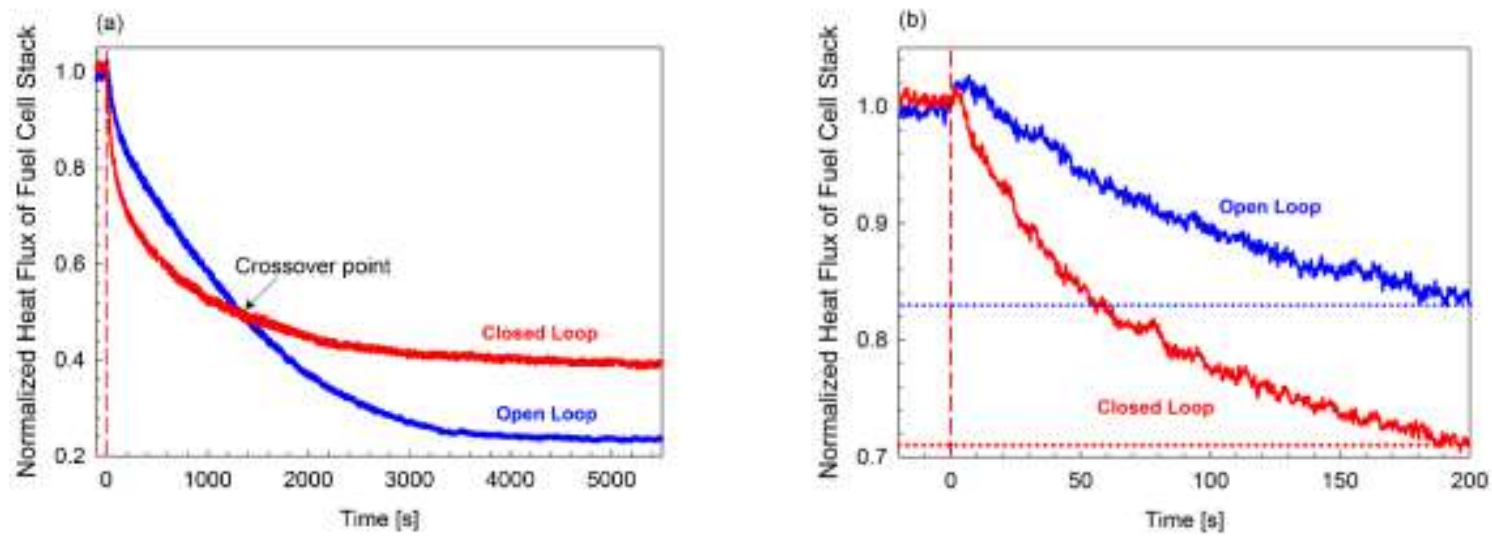

Figure 13: Normalized profiles of total heat flux in a fuel cell stack for open loop and closed loop, (a) Over $5,500 \mathrm{~s}$ of test period, (b) Over the first $200 \mathrm{~s}$ after fuel composition transition

At 5,500 s, the beginning of the cell was heated by the airflow, while the remainder of the fuel cell was cooled by the airflow. This was a consequence of decreasing fuel cell solid temperature toward the end of the test and the methane reformation region shifting further down the fuel cell length.

The normalized profiles of the total heat flux in the fuel stack for both operation modes are shown in Figure 13. The initial values for the open loop and closed loop tests were $62 \mathrm{~kW}$ and $61 \mathrm{~kW}$ respectively. As shown in Figure 13a, the crossover point in the heat flux was achieved approximately at 1,300 $\mathrm{s}$ after using humidified methane, as the heat flux dropped to about 50\% from their initial values. Owing to the lower cathode inlet air temperature at higher airflow within the first $1,300 \mathrm{~s}$, the total heat flux in the open loop case was higher than in the closed loop. These trends are clearly represented by the dynamic response over the first $200 \mathrm{~s}$ as shown in Figure 13b, indicating a $17 \%$ reduction in the open loop system and near to $30 \%$ reduction in the closed loop system. However, a $12 \%$ reduction in cathode air mass flow over 5,500 s of the open loop test ultimately resulted in an $80 \%$ decrease in the total heat flux. In contrast, with constant cathode air flow, the total heat flux for the closed loop only reduced by about $60 \%$ from the initial values.

\section{Fuel Cell Heat Generation}

The detailed response in heat generation $(H G)$ on an area specific basis is shown in Figure 14. In this work, heat generation for an operating fuel cell was calculated using Eq. 7. Heat loss to the surrounding was neglected in the model because this was physically attributed by the hardware system.

Fuel cell heat generation:

$H G=H G_{\text {cell }}+H G_{S M R}+H G_{W G S}$

The terms of $H G_{c e l l}, H G_{S M R}$, and $H G_{W G S}$ respectively represent the by-product heat generation from the electrochemical oxidation polarizations, heat generation from steam methane reforming (which is negative), and water-gas shift reactions.

As illustrated in Figure 14a, heat generation at the beginning of the cell reduced dramatically immediately after the fuel composition switch, following by a slow increase toward the new steady state at $5,500 \mathrm{~s}$. The heat generation profile obtained from the open loop was similar to the closed loop profiles, as shown in Figure 14b. 

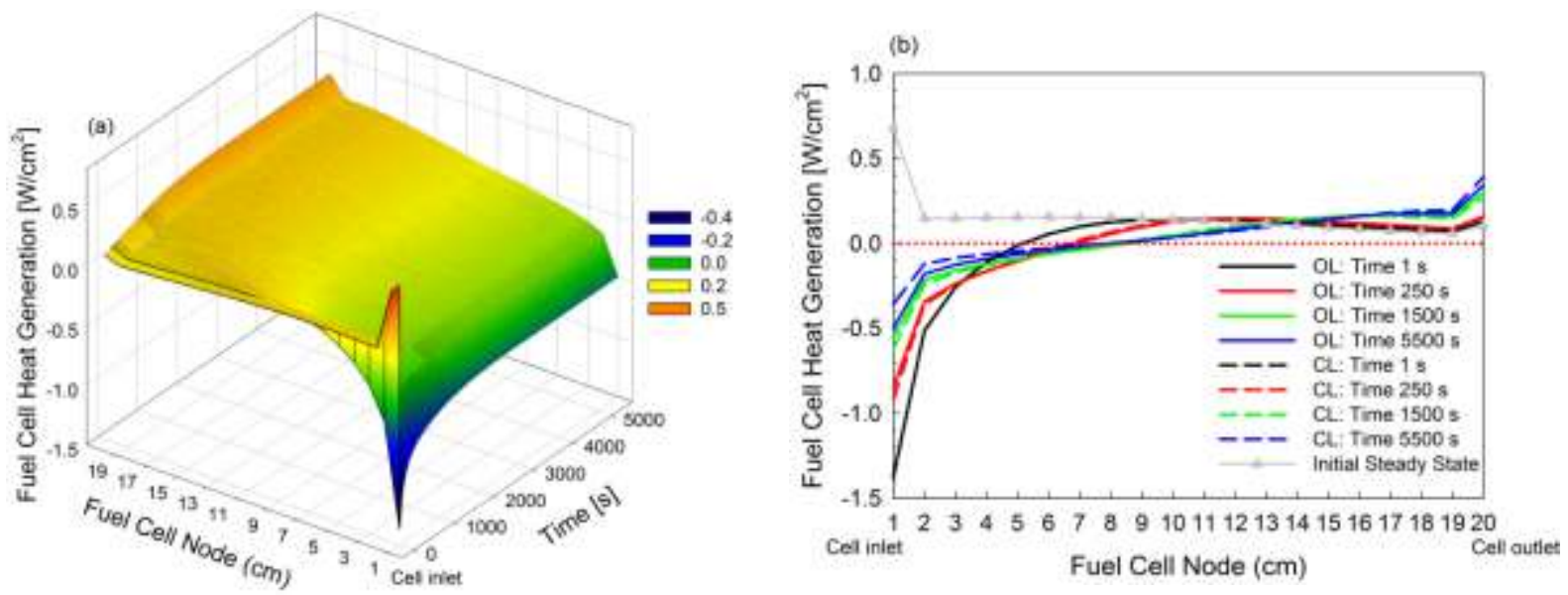

Figure 14: Fuel cell heat generation as a function of time, (a) Open loop transient response (b) Comparison of open loop and closed loop transients

The magnitude of heat generation at the initial steady state in Figure $14 \mathrm{~b}$ matched the magnitude of heat flux shown in Figure 12b. Therefore, the system exhibited fairly constant solid and gas temperature performance, respectively presented in Figures 5 and 8. However, as the fuel was changed to humidified methane, heat generation at the cell entrance reduced significantly from $0.7 \mathrm{~W} / \mathrm{cm}^{2}$ to about $-1.4 \mathrm{~W} / \mathrm{cm}^{2}$. This initial transient was promoted by heat utilization in the steam methane reforming reaction. As compared to the heat flux profile in Figure 12b, no significant fluctuation in heat flux was observed at $1 \mathrm{~s}$ after the step change due to delay in temperature dynamics.

Heat generation at the cell entrance shown in Figure 14b increased gradually as the test progressed. To be specific, the magnitude of heat generation at the beginning of the cell decreased with decreasing methane conversion as the fuel cell solid temperature decreased. Because of the insignificant difference in $\mathrm{CH}_{4} \mathrm{~mole}$ fraction at $1 \mathrm{~s}$ between the open loop and closed loop tests (Figure 15), the same profiles of heat generation density were obtained. However, heat generation at the beginning of the cell from both operations started to deviate slowly throughout the test, which reflected to the trends in $\mathrm{CH}_{4}$ mole fraction and the corresponding fuel cell solid temperature.

The same impacts were also demonstrated at around center of the cell length. Heat generation decreased over time as more $\mathrm{CH}_{4}$ mole fraction shifted toward the elevated temperature region at the second half of the fuel cell length. In contrast, heat generation at the back of the cell gradually increased over the time studied due to electrochemical reactions. This behavior was found to be consistent with the trends in current density.

Since the inlet temperature at the end of the open loop test was higher than in the closed loop, more methane reforming was facilitated. Hence, the heat generation in the open loop case was more strongly negative, as depicted by the profile at 5,500 s in Figure 14b. At 5,500 s, the total average heat generation of the stack was $14.5 \mathrm{~kW}$, which was comparable to the $14.7 \mathrm{~kW}$ of heat flux shown in Figure 12, indicating that the system achieved a new steady state.

\subsection{Transient Analysis of Fuel Compositions, Current Density, and Fuel Utilization}

\section{Methane, $\mathrm{CH}_{4}$}

The variations in methane mole fraction along the length of the cell are presented in Figure 15. As shown in Figure 15a, methane was consumed in the system over the entire course of the experiment, reducing from the inlet composition at node 1 to near zero mole fractions at the cell outlet. Meanwhile, Figure 15b compares the changes in $\mathrm{CH}_{4}$ mole fraction resulting from the open loop and closed loop operations. 

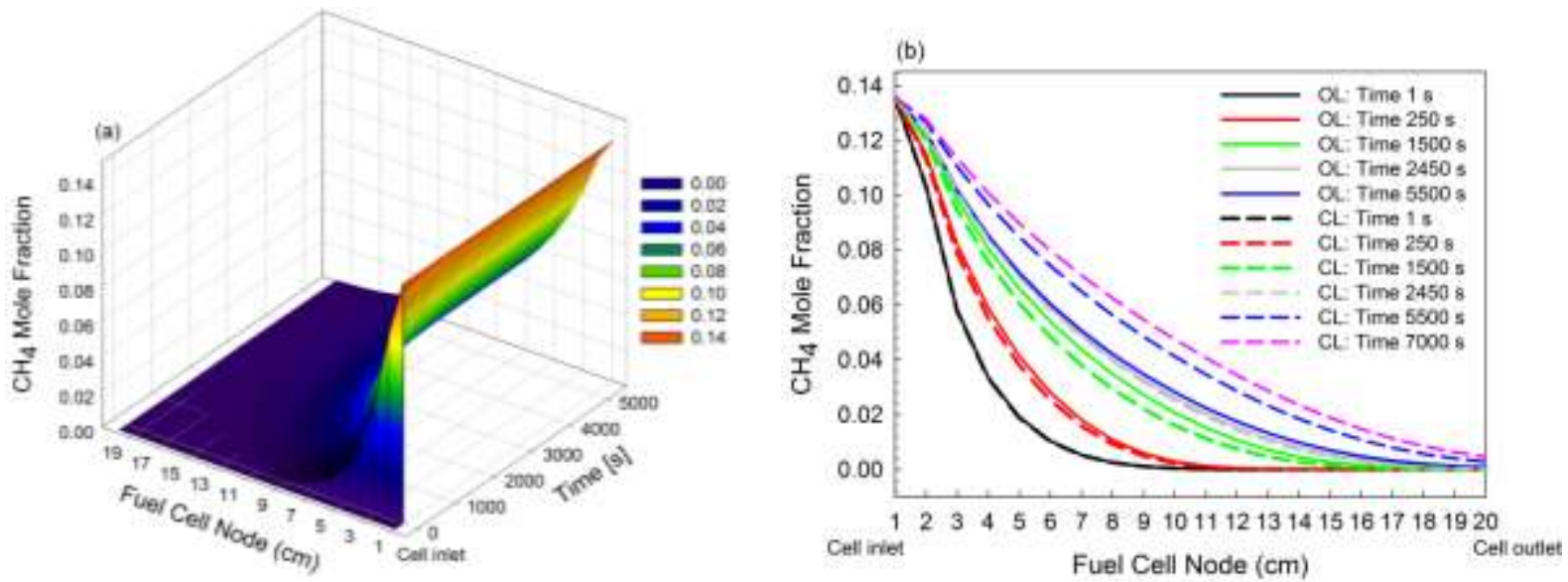

Figure 15: Methane mole fraction as a function of time, (a) Open loop transient response (b) Comparison of open loop and closed loop transients

Within the first 2,450 s after the step change in fuel composition, $\mathrm{CH}_{4}$ reduced more slowly in the variable turbine speed operation, as compared to the constant turbine speed operation. The lower $\mathrm{CH}_{4}$ consumption (in open loop) was mainly due to lower fuel cell solid temperature as demonstrated in Figure 5a. The increased cathode air mass flow during the first transient period in the open loop reduced solid temperature. As such, methane reforming decelerated, resulting in lower $\mathrm{CH}_{4}$ consumption. In contrast, faster conversion of methane in the closed loop test was promoted by its higher operating temperature, as shown in Figure 5.

The reduction in cathode air mass flow in the open loop system subsequently induced the rapid depletion of $\mathrm{CH}_{4}$ in the fuel cell subsystem. As shown in Figure 15b, the open loop dynamics obtained at 2,450 s followed the closed loop dynamics very closely. Both methane mole fraction and solid temperature crossover points were identical, suggesting close coupling of reforming to solid temperature. If this is the case, composition transients could be mitigated using cathode airflow modulation, which has been shown to have a strong impact on solid temperature.

\section{Other Fuel Composition Gradients, Current Density, and Fuel Utilization}

The corresponding effects on other fuel constituents, such as $\mathrm{CO}, \mathrm{H}_{2}$, and $\mathrm{H}_{2} \mathrm{O}$ are respectively presented in Figure 16 through Figure 18. The slower and consequent rate limiting $\mathrm{CH}_{4}$ reforming influenced the formation and consumption of the other fuel components in water-gas shift and electrochemical oxidation.

Because of higher temperature at the initial steady state shown in Figure 5, the system was more dominated by endothermic methane reforming rather than water-gas shifting. Therefore, both $\mathrm{CO}$ and $\mathrm{H}_{2}$ mole fraction at the first half of the cell length shown in Figures 16 and 17 increased with decreasing $\mathrm{CH}_{4} \mathrm{~mole}$ fraction (Figure 15). As expected, $\mathrm{H}_{2} \mathrm{O}$ mole fraction shown in Figure 18, significantly reduced in the beginning of the cell. Due to less $\mathrm{CH}_{4}$ in the downstream region, $\mathrm{CO}$ and $\mathrm{H}_{2}$ mole fraction reduced gradually when a transition in the water-gas shift reaction toward the product side and electrochemical oxidation of $\mathrm{H}_{2}$ became more significant. Higher formation of $\mathrm{H}_{2} \mathrm{O}$ that was reflected by consumption of $\mathrm{H}_{2}$ was still observed at the end of the cell.
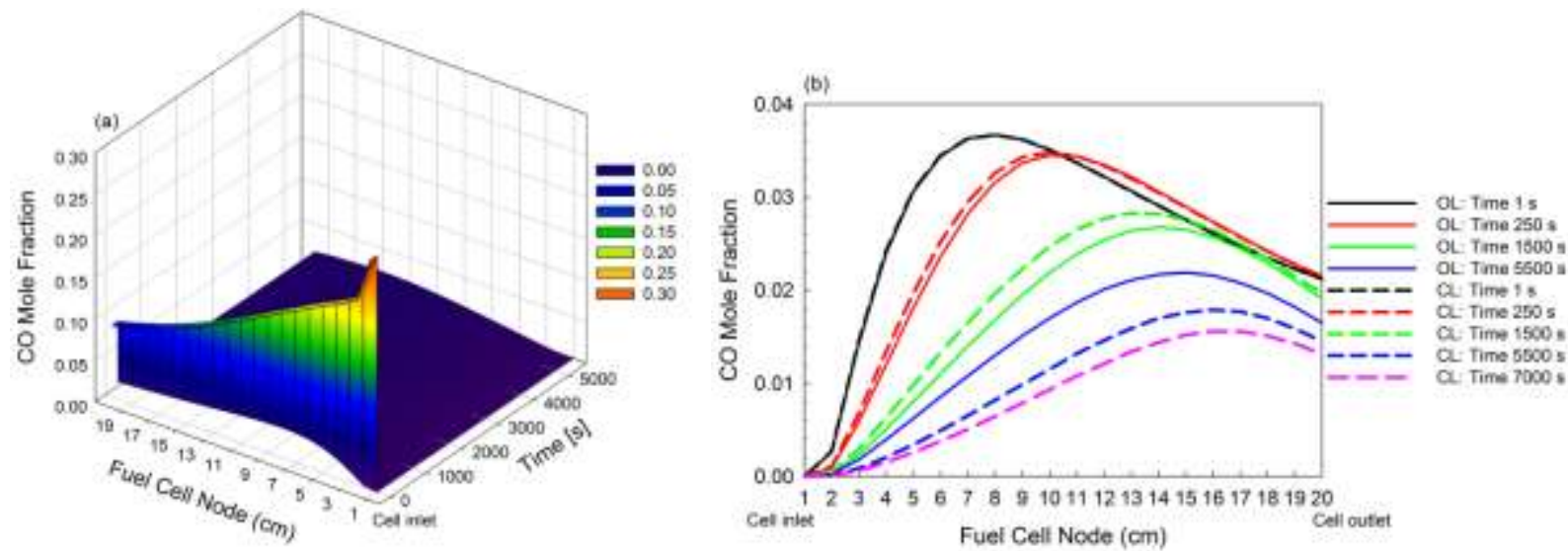

Figure 16: Carbon monoxide mole fraction as a function of time, (a) Open loop transient response (b) Comparison of open loop and closed loop transients 
Immediately after the fuel composition change, the current density shown in Figure 19 increased to a maximum value around node 6 to node 8. The $\mathrm{H}_{2}$ mole fraction was also at the maximum (Figure 17), suggesting the formation of $\mathrm{H}_{2}$ from steam methane reforming was significantly higher than its consumption in the electrochemical oxidation. High $\mathrm{CO}$ generation rate provides further evidence of sufficient reforming to maintain the water gas shift equilibrium toward the reactant side (Eq. 2). Despite the maximum localized current density, the fuel utilization was at a local minimum near node 6, as shown in Figure 20 for the $1 \mathrm{~s}$ curve. This clearly indicated that large amounts of thermal energy in the fuel cell were being converted to chemical energy in this region. Hence, this caused more reduction in solid temperature at the beginning of the cell. As there was less energy in the cell, represented by lower temperature and thereby lower sensible heat, methane became more distributed and the $\mathrm{H}_{2}$ partial pressure reduced.
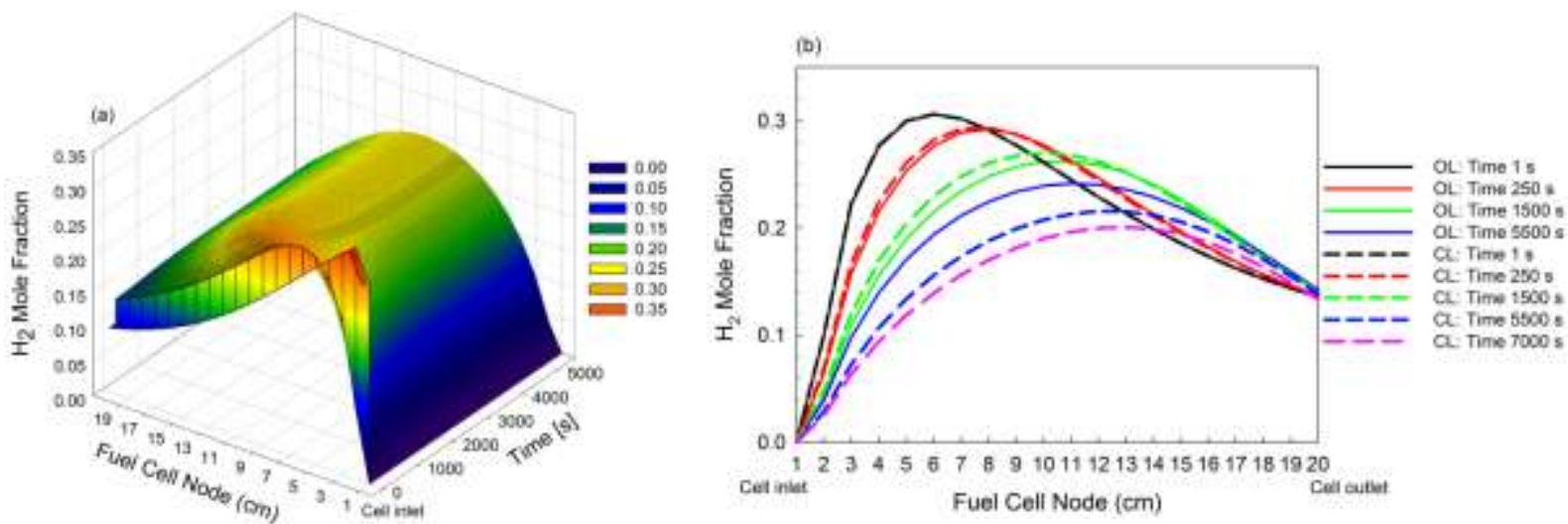

Figure 17: Hydrogen mole fraction as a function of time, (a) Open loop transient response (b) Comparison of open loop and closed loop transients

The open loop system experienced a solid temperature drop by $50 \mathrm{~K}$ drop in just $250 \mathrm{~s}$. Following the deceleration of $\mathrm{CH}_{4}$ reforming at more rapid solid temperature drop in the open loop case, the reduction in $\mathrm{CO}$ and $\mathrm{H}_{2}$ mole fractions were seen to be more apparent in the open loop test as compared to the closed loop test. The corresponding conductivity likewise reduced. The maximum current density region significantly shifted from the beginning of the cell, before the fuel composition switch, to further down the cell towards the end of the test. The same current density profiles were observed in the open loop and closed loop tests within the first $250 \mathrm{~s}$ due to very slight differences in the solid temperature and fuel composition dynamics.

As approaching a new steady state in the open loop case approximately at 5,500 s, the $\mathrm{CO}$ and $\mathrm{H}_{2}$ mole fractions in the open loop case did not reduce as much as in the closed loop. The open loop test demonstrated higher maximum $\mathrm{CO}$ and $\mathrm{H}_{2}$ mole fraction at 5,500 s, respectively with $22 \%$ and $12 \%$ relative differences to the maximum value in the closed loop case. This was attributed to the higher solid temperature in the open loop case. The higher temperature would favor reforming and inhibit water gas shift as written in Eq. 2, both of which result in higher $\mathrm{CO}$ partial pressures.
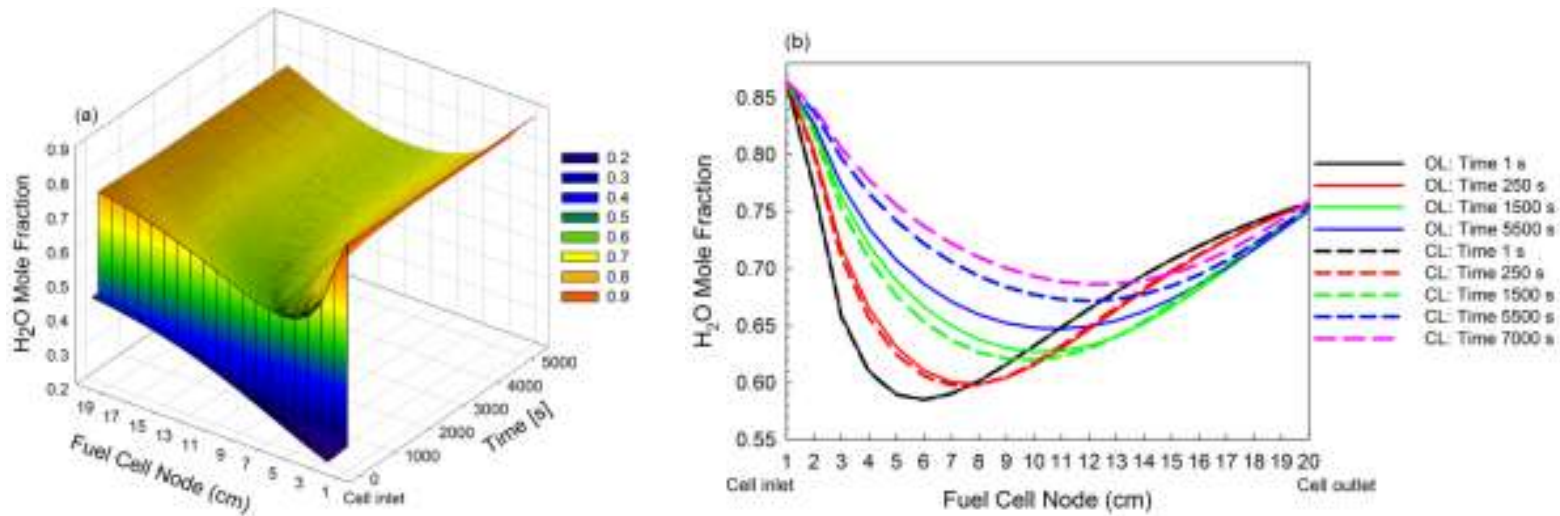

Figure 18: Water mole fraction as a function of time, (a) Open loop transient response (b) Comparison of open loop and closed loop transients 
In fact, the maximum current density at 1,500 s and 5,500 s were also nearly identical and the curves were close, having come to equilibrium much faster than in the closed loop case. In contrast, an $8 \%$ higher current density was still noticeable at 5,500 $\mathrm{s}$ in the closed loop test, as a consequence of continuous changes in temperature and fuel composition partial pressures. At 5,500 s, current density increased with reduction in $\mathrm{H}_{2}$ mole fraction near the cell exit, both of which promoted higher fuel utilization.

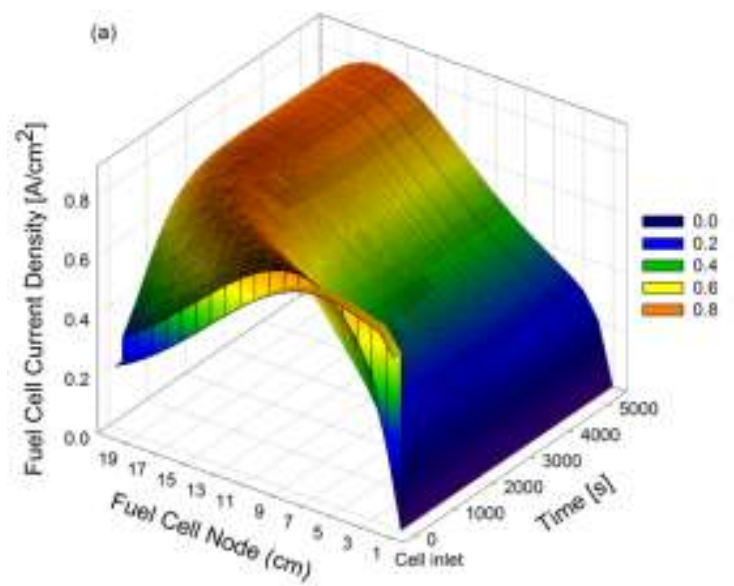

(b)

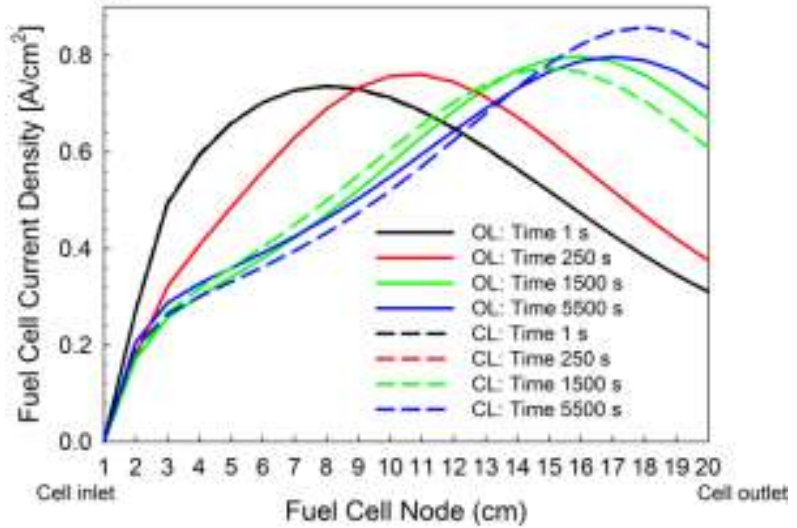

Figure 19: Fuel cell current density as a function of time (a) Open loop transient response (b) Comparison of open loop and closed loop transients

\subsection{Transient Analysis of Fuel Cell Thermal Energy Storage and Fuel Cell Thermal Effluent}

The dissipation of fuel cell stored thermal energy and the corresponding fuel cell thermal effluent in response to the fuel composition changes are shown in Figure 21, where dissipation represents the change in rate of thermal energy being stored in the fuel cell stack. The dissipation term was calculated based on the rate of change in fuel cell average temperature multiplied with the total stack heat capacity as function of temperature ( $2625 \mathrm{~kJ} / \mathrm{K}$ at the initial condition), as summarized in Eq. 8. The initial fuel cell stored thermal energy shown in Figure 21a reduced immediately as a result of the accelerated steam methane reforming. The increasing $\mathrm{H}_{2}$ generation at $1 \mathrm{~s}$ clearly illustrated the associated dynamic conversion of thermal energy to chemical energy, which subsequently resulted in lower fuel utilization within increased current density region. Such transients finally caused a dramatic increase in fuel cell thermal effluent exiting the system indicated in Figure 21b. The system experienced a significant reduction in solid temperature as the stored thermal energy decreased. As compared to the closed loop transients, the dissipation of stored thermal energy in the open loop case recovered more gradually before the crossover point at 1,300 s. However, the new steady state in the open loop was achieved far quicker than in the closed loop due to the coupling of the cathode air mass flow in a longer test run.

The difference in the fuel cell thermal effluent between the open loop and closed loop cases shown in Figure $21 \mathrm{~b}$ was attributed primarily to the difference in dissipation of stored thermal energy. The dynamic fuel cell thermal effluent remained higher than the initial value for about 1,600 s before decreasing to the new steady state, following non-minimum phase behavior (transient inverse response) as opposed to its initial steady state performance [17]. This ultimately caused the initial 4\% rapid increase in turbine speed and $8 \%$ increase in 
cathode air mass flow (Figure 3). The overshoot response in fuel cell thermal effluent was identified as one of the main operational challenges to fuel flexibility in gas turbine hybrid systems. It is critical to develop novel control strategies to limit such overshoot and expand the range of fuel composition changes that could be implemented.

Nonlinear control models are required to describe the entire trajectories of the fuel cell thermal effluent.

Dissipation of fuel cell stored thermal energy:

$$
=\frac{d T_{\text {ave }}}{d t} x \text { total stack heat capacity }\left(2625 \frac{\mathrm{kJ}}{\mathrm{K}}\right)
$$
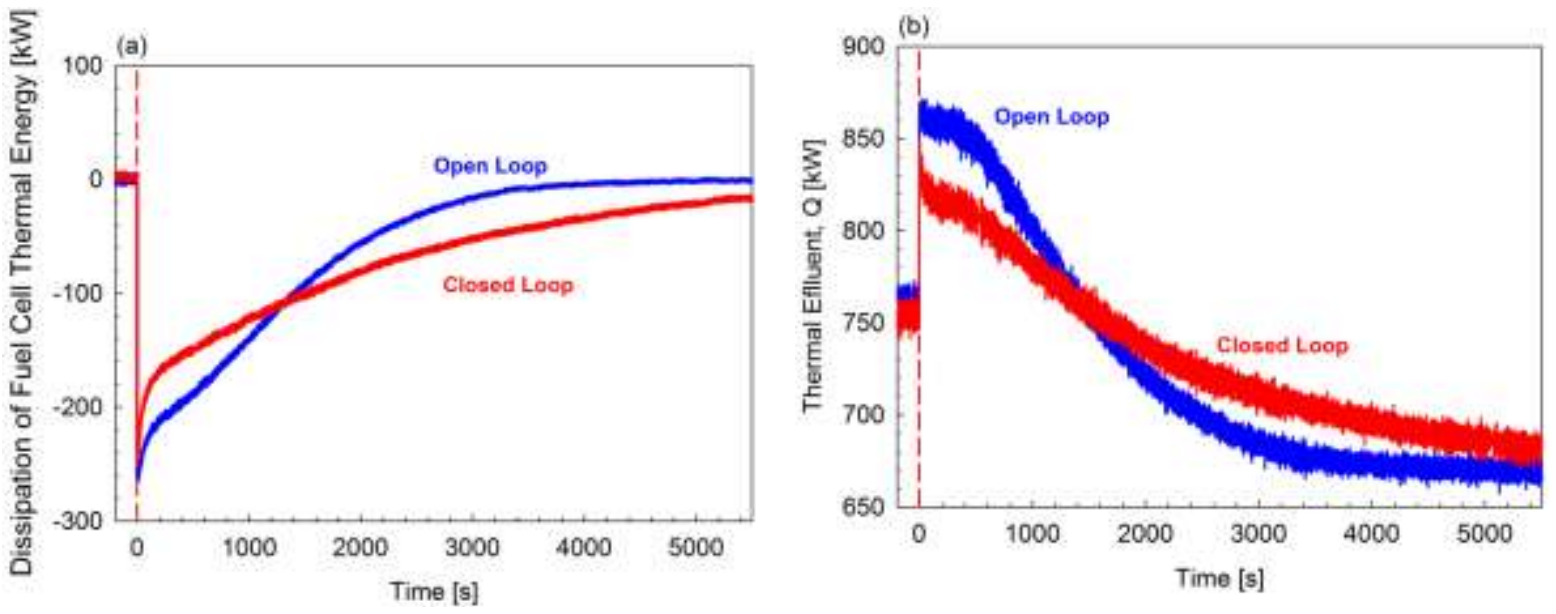

Figure 21: Changes in fuel cell stored energy and fuel cell thermal effluent for the open loop and the closed loop tests

\section{Conclusions}

The detailed dynamic characterization of an SOFC/GT hybrid system under a transition from syngas to humidified methane revealed:

a. An extensive conversion of fuel cell stored thermal energy immediately after the step change, resulting in a sudden transient inverse response in fuel cell transferred heat,

b. A spike in thermal effluent from the fuel cell post combustor system to the turbine, which occurred in spite of a dramatic reduction in both heat generation and heat flux, which was dominated by the conversion of stored thermal energy to chemical energy,

c. A substantial solid temperature drop $(50 \mathrm{~K})$ in the fuel cell $250 \mathrm{~s}$ after the step change due to propagation impacts of increased cathode air mass flow,

d. A maximum of $17 \mathrm{~K} / \mathrm{cm}$ solid temperature gradient in the fuel cell from an initial state of $12 \mathrm{~K} / \mathrm{cm}$,

e. Significant differences in the distributed performance of temperature, heat flux, heat generation, composition gradients, fuel utilization, and especially current density,

f. Substantial cathode air flow coupling effects over the course of the entire study from the initial change to the new steady state,

g. Close coupling between the steam methane reforming and solid temperature.

The open loop operation demonstrated significant variations in turbine speed and cathode mass flow. As much as $6 \%$ turbine speed variation from nominal condition was observed. Hence, the system experienced a $12 \%$ cathode air mass flow change. Therefore, fuel cell temperature, heat flux, and temperature gradient across the fuel cell length changed accordingly due to highly coupling effects. However, this perturbation helped the system to achieve a new steady state faster than the closed loop system.

As compared to the closed loop, operating the SOFC/GT hybrid system with turbine speed changes resulted in less detrimental performance after the crossover points, with higher temperature, lower current density, and lower fuel utilization. We also found that small changes in turbine efficiency at higher speed in the open loop over the closed loop tests affected fuel cell heat flux through variations in cathode air inlet temperature. Overall, all key fuel cell parameters were highly coupled and solid temperature appeared to be the primary linking event of many mechanisms. 
In conclusion, fuel cell solid temperature control is critical to avoid excessive temperature gradients, which could not be tolerated by the fuel cell material. Severe cooling effects might be also localized at the beginning of the cell, depending on the initial methane content. So, a shorter cell lifetime would be expected due to increasing degradation risk since the system was operated at a lower temperature. Therefore, future dynamic control systems for SOFC/GT hybrid systems must include effective thermal management, most likely implemented through cathode air flow management. Nonlinear control strategies must be employed to deal with the system complexity adequately. It is clear from the comparison of open and closed loop transient study that cathode airflow has the strongest linking effect on fuel composition changes, and it holds the greatest promise for active control in fuel flexible systems.

\section{Acknowledgements}

This work was funded by the U.S Department of Energy Crosscutting Research program, implemented through the Technology Development \& Integration Center, Coal, in The Office of Fossil Energy. The authors would like to thank Nana Zhou, Paolo Pezzini, Valentina Zaccaria, and Dave Ruehl from NETL for their contribution in the execution of the experimentation, and also greatly acknowledge the Universiti Teknologi Malaysia for financial support.

\section{Disclaimer}

This report was prepared as an account of work sponsored by an agency of the United States Government. Neither the United States Government nor any agency thereof, nor any of their employees, makes any warranty, express or implied, or assumes any legal liability or responsibility for the accuracy, completeness, or usefulness of any information, apparatus, product, or process disclosed, or represents that its use would not infringe privately owned rights. Reference therein to any specific commercial product, process, or service by trade name, trademark, manufacturer, or otherwise does not necessarily constitute or imply its endorsement, recommendation, or favoring by the United States Government or any agency thereof. The views and opinions of authors expressed therein do not necessarily state or reflect those of the United States Government or any agency thereof.

\section{References}

[1] Buonomano A, Calise F, d'Accadia MD, Palombo A, Vicidomini M. Hybrid solid oxide fuel cells-gas turbine systems for combined heat and power: A review. Appl Energy 2015;156:32-85.

[2] Adams TA II, Nease J, Tucker D, Barton PI. Energy conversion with solid oxide fuel cell systems: A review of concepts and outlooks for the short- and long-term. Ind Eng Chem Res 2013;52:3089-3111.

[3] Winkler W, Nehter P, Williams MC, Tucker D, Gemmen R. General fuel cell hybrid synergies and hybrid system testing status. J Power Sources 2006;159:656-666.

[4] Tucker D, Abreu-Sepulveda M, Harun NF. SOFC lifetime assessment in gas turbine hybrid power systems. ASME J Fuel Cell Sci and Technol 2014;11:051008-0510008-7.

[5] Tucker D, Liese E, VanOsdol JG, Lawson LO, Gemmen RS. Fuel cell gas turbine hybrid simulation facility design. ASME International Mechanical Engineering Congress and Exposition. New Orleans, Los Angeles, U.S.A; 2002. ASME Paper No. IMECE2002-33207.

[6] Chen Y, Adams TA II, Barton PI. Optimal design and operation of flexible energy polygeneration systems. Ind Eng Chem Res 2011;50:4553-4566.

[7] Yi Y, Rao AD, Brouwer J, Samuelsen GS. Fuel flexibility study of an integrated $25 \mathrm{kw}$ SOFC reformer system. J Power Sources 2005;144:67-76.

[8] McIntosh S, Gorte RJ. Direct hydrocarbon solid oxide fuel cells. Chemical Reviews 2004;104:4845-66.

[9] Harun NF, Tucker D, Adams TA II. Impact of fuel composition transients on SOFC performance in gas turbine hybrid systems. Appl Energy 2016;164:446-461.

[10] Zaccaria V, Tucker D, Traverso A. A distributed real-time model of degradation in a solid oxide fuel cell, part I: Model characterization. J Power Sources 2016;311:175-181.

[11] McLarty D, Kuniba Y, Brouwer J, Samuelsen S. Experimental and theoretical evidence for control requirements in solid oxide fuel cell gas turbine hybrid systems. J Power Sources 2012;209:195-203.

[12] Song TW, Sohn JL, Kim TS, Ro ST. Performance characteristics of a MW-class SOFC/GT hybrid system based on a commercially available gas turbine. J Power Sources 2005;158:361-367.

[13] Traverso A, Magistri L, Massardo AF. Turbomachinery for the air management and energy recovery in fuel cell gas turbine hybrid systems. Energy 2010;35:764-777.

[14] Nakajo A, Wuillemin Z, Herle JV, Favrat D. Simulation of thermal stress in anode-supported solid oxide fuel cell stacks. Part I: Probability of failure of the cells. J Power Sources 2009;193:201-215. 
[15] Pezzini P, Traverso A, Banta L, Tucker D. Decentralized control strategy for fuel cell turbine hybrid systems. The 57th Annual ISA Power Industry Division Symposium. Scottsdale, Arizona, USA; 2014; ; Paper No. ISA-PWID2015-52.

[16] Pezzini P, Tucker D, Traverso A. Avoiding compressor surge during emergency shut-down hybrid turbine systems. ASME J Eng Gas Turbines Power 2013;135:102602-102602-10.

[17] Harun NF, Tucker D, Adams TA II. Fuel composition transients in fuel cell turbine hybrid for polygeneration applications. ASME J Fuel Cell Sci Technol 2014;11:061001-061001-8.

[18] Santin M, Traverso A, Magistri L. Liquid fuel utilization in SOFC hybrid systems. Appl Energy 2009;86:2204-2212.

[19] Facchinetti E, Gassner M, D’Amelio M, Marechal F, Favrat D. Process integration and optimization of a solid oxide fuel cell - Gas turbine hybrid cycle fueled with hydrothermally gasified waste biomass. Energy 2012;41:408-419.

[20] Adams TA II, Barton PI. Combining coal gasification, natural gas reforming, and solid oxide fuel cells for efficient polygeneration with $\mathrm{CO}_{2}$ capture and sequestration. Fuel Processing Technol 2011;92:2105-2115.

[21] Yang WJ, Park SK, Kim TS, Kim JH, Sohn JL, Ro ST. Design performance analysis of pressurized solid oxide fuel cell/gas turbine hybrid systems considering temperature constraints. J Power Sources 2006;160:462743.

[22] Chatrattanawet N, Skogestad S, Arpornwichanop A. Control structure design and dynamic modeling for a solid oxide fuel cell with direct internal reforming of methane. Chem Eng Res Des 2015;98:202-211.

[23] Mueller F, Jabbari F, Brouwer J. On the intrinsic transient capability and limitations of solid oxide fuel cell systems. J Power Sources 2009;187:452-460.

[24] Fardadi M, Mueller F, Jabbari F. Feedback control of solid oxide fuel cell spatial temperature variation. J Power Sources 2010;195:4222-4233.

[25] Komatsu Y, Kimijima S, Szmyd JS. Numerical analysis on dynamic behavior of solid oxide fuel cell with power output control scheme. J Power Sources 2013;223:232-245.

[26] Kaneko T, Brouwer J, Samuelsen GS. Power and temperature control of fluctuating biomass gas fueled solid oxide fuel cell and micro gas turbine hybrid system. J Power Sources 2006;160:316-325.

[27] Mueller F, Jabbari F, Brouwer J, Roberts R, Junker T, Ghezel-Ayagh H. Control design for a bottoming solid oxide fuel cell gas turbine hybrid system. ASME J Fuel Cell Sci Technol 2006;4:221-230.

[28] Roberts RA, Brouwer J, Samuelsen GS. Fuel cell/gas turbine hybrid system control for daily load profile and ambient condition variation. ASME J Eng Gas Turbines Power 2010;132:012302-012302-7.

[29] Jiang W, Fang R, Khan J, Dougal R. Control strategies for start-up and part-load operation of solid oxide fuel cell/gas turbine hybrid system. ASME J Fuel Cell Sci Technol 2009;7:011016-011016-9.

[30] Stiller C, Thorud B, Bolland O, Kandepu R, Imsland L. Control strategy for a solid oxide fuel cell and gas turbine hybrid system. J Power Sources 2006;158:303-315.

[31] McLarty D, Brouwer J, Samuelsen S. Fuel cell-gas turbine hybrid system design part II: Dynamics and control. J Power Sources 2014;254:126-136.

[32] Harun NF, Tucker D, Adams TA II. Open loop and closed loop performance of solid oxide fuel cell gas turbine hybrid systems during fuel composition changes. ASME Turbo Expo 2015: Turbine Technical Conference and Exposition. Montréal, Canada; 2015. ASME Paper No. GT2015-43609.

[33] Tucker D, Lawson L, Gemmen R, Dennis R. Evaluation of hybrid fuel cell turbine system startup with compressor bleed. ASME Turbo Expo 2005. Reno, NV, USA; 2005. p. 333-341. ASME Paper No. GT200568784.

[34] Tucker D, Liese E, Gemmen R. Determination of the operating envelope for a direct fired fuel cell turbine hybrid using hardware based simulation. International Colloquium on Environmentally Preferred Advanced Power Generation (ICEPAG) 2009. Newport Beach, California, USA; 2009. Paper No. ICEPAG2009-1021.

[35] Tucker D, Pezzini P, Banta L. Equivalence ratio startup control of a fuel cell turbine hybrid system. ASME Turbo Expo 2013: Power for Land, Sea and Air. San Antonio, Texas, USA; 2013. ASME Paper No.GT201394809.

[36] Hughes D, Wepfer WJ, Davies K, Ford JC, Haynes C, Tucker D. A real-time spatial SOFC model for hardware-based simulation of hybrid systems. ASME 20119 th International Conference on Fuel Cell Science, Engineering and Technology collocated with ASME 2011 5th International Conference on Energy Sustainability. Washington, DC, USA; 2011. ASME Paper No. ESFuelCell2011-54591.

[37] EG\&G Technical Services I. Fuel Cell Handbook. Seventh Edition ed. Morgantown, West Virginia: U.S. Department of Energy, Office of Fossil Energy, National Energy Technology Laboratory; 2004.

[38] Tucker D, Hughes D, Haynes C. IGFC response to initial fuel cell load for various syngas compositions. ASME 2011 9th International Conference on Fuel Cell Science, Engineering and Technology collocated with ASME 2011 5th International Conference on Energy Sustainability. Washington DC, USA; 2011. ASME Paper No. ESFuelCell2011-54450. 
[39] Eguchi K, Kojo H, Takeguchi T, Kikuchi R, Sasaki K. Fuel flexibility in power generation by solid oxide fuel cells. J. Solid State Ionics 2002;152-153:411-416.

[40] Hughes DO. A hardware-based transient characterization of electrochemical start-up in an SOFC/gas turbine hybrid environment using a 1-D real time SOFC model. Atlanta, Georgia: Georgia Institute of Technology; 2011.

[41] Aguiar P, Adjiman CS, Brandon NP. Anode-supported intermediate temperature direct internal reforming solid oxide fuel cell. I: model-based steady-state performance. Journal of Power Sources. 2004;138:120-36. 